\title{
Orígenes del fotomatón en España (1888-1929)
}

\author{
Celia Vega PÉREZ \\ Universidad Complutense de Madrid. Departamento de Comunicación Audiovisual \\ cevega@ucm.es
}

Recibido: Octubre 2014

Aceptado: Noviembre 2014

Resumen: En la Exposición Universal de Barcelona de 1888, Juan Cantó presentó en España por primera vez una máquina de fotografía automática precedente del fotomatón. Desde entonces hasta 1929, fecha en la que se abre el primer estudio Photomaton y se instalan los primeros aparatos Fotodin, se patentaron en España diferentes modelos de máquinas automáticas de retratar. El objeto de este trabajo es realizar un estudio histórico sobre los orígenes del fotomatón y sus antecedentes a través de las patentes de invención e introducción de aparatos de fotografía automáticas solicitadas, concedidas y puestas en práctica entre 1888 y 1929, y de las empresas pioneras en la explotación, venta y alquiler de estos dispositivos.

Palabras clave: Fotografía automática; Fotomatón; Fotodin; Historia de la Fotografía en España.

\section{Origins of the Photobooth in Spain (1888-1929)}

\begin{abstract}
In the 1888 Barcelona Universal Exposition, Juan Cantó showed, for the first time in Spain, his automatic photography machine, a precedent of the photobooth. Since the until 1929, the date on which the first Photomaton studio was open and the first Fotodin devices were installed, different models of automatic photography machines were patented in Spain. This study reviews the history of the early years of the booth and its antecedents through patents of automatic photography apparatus between 1888 and 1929, and the pioneering companies in the exploitation, sale and rental of these devices.
\end{abstract}

Keywords: Automatic photography; Photobooth; Fotodin; History of Photography in Spain.

\section{INTRODUCCIÓN: OBJETIVOS, FUENTES Y METODOLOGÍA}

El fotomatón fue inventado como tal en 1925 en Estados Unidos por el siberiano Anatol Josepho, aunque contaba con una larga lista de precedentes. El aparato de Josepho llegó a España en 1929, pese a que, una vez más, pueden encontrarse en nuestro país máquinas de fotografía automática en funcionamiento ya en el año 1888. Este artículo recoge el momento inicial de esta industria en España a través de las patentes de invención e introducción de aparatos de fotografía automática solicitadas, concedidas y puestas en práctica entre 1888 y 1929, y de las empresas pioneras en la explotación, venta y alquiler de estos dispositivos, un tema inédito y que viene a completar la bibliografía existente sobre la historia de la fotografía nacional. Para ello se fijaron los siguientes objetivos: 1) establecer cuándo y cómo 
se introduce la fotografía automática en España y cuáles fueron las primeras ciudades en las que se desarrolló esta práctica, 2) conocer las empresas pioneras que se dedicaron a la construcción, explotación y venta de aparatos de fotografía automática en España y su relación con los fotógrafos de estudio 3) observar el impacto del fotomatón en la sociedad española del primer tercio del siglo XX y 4) determinar los diferentes usos posibles del fotomatón.

Este artículo funciona, por tanto, como punto de partida para una futura historia del fotomatón en España y se espera con él haber avanzado en el conocimiento de una parte de la historia de la industria fotográfica que ha sido sistemáticamente olvidada en las publicaciones generales que tratan la Historia de la Fotografia, y a la que apenas se ha prestado atención en estudios puntuales. En última instancia se pretende demostrar la importancia del fotomatón en el proceso de democratización y popularización de la imagen fotográfica que comienza con la carte de visite, pero sobre todo adquiere gran impulso con la aparición de kodak. En mitad de este proceso, el fotomatón, a medio camino entre la fotografía profesional y la práctica amateur, cumple una doble función: por un lado es utilizado como máquina de recreo; y, por otro, dispensa retratos para documentos oficiales. También se busca analizar y medir el impacto que tuvo la introducción del fotomatón en España a nivel industrial, social y cultural, y su relación con el panorama internacional. Para ello se procederá al análisis de una muestra de fotografías y al estudio de las mismas.

Dentro de las fuentes primarias, la información más valiosa fue obtenida de los expedientes de patentes conservados en el Archivo Histórico de la Oficina Española de Patentes y Marcas. También se han consultado el Anuario Financiero $y$ de Sociedades Anónimas de España de 1930, y los "certificados literales" de las siguientes sociedades: Sociedad Auto Fotográfica SA, Sociedad Española de Fotografía Automática y Sociedad Española Photomaton "La fotografía perfecta", las tres empresas dedicadas a la comercialización de aparatos de fotografía automática más importantes de España entre 1893 y 1930. Los datos que recogen estos documentos, aunque en ocasiones clave, son en general escasos y muchas veces reiterativos.

Para los aspectos generales sobre la historia de la fotografía se han consultado las siguientes obras de referencia: Frizot (2001), Fontcuberta (2012), López Mondejar (2005), Sánchez Vigil (2006) y Sougez (2009). En lo que respecta a la historia específica del fotomatón todos los títulos consultados son extranjeros, sin traducción al castellano, y en ninguno se trata el caso español. Goranin (2008) es la referencia fundamental a la hora de documentarse acerca de la historia del fotomatón en Estados Unidos, y por ende a la historia general de este fenómeno, puesto que es en el país norteamericano donde se origina. Raynal Pellicer en su libro Photobooth. The Art of the Automatic Portrait dedica un capítulo a los orígenes de la fotografía automática, hablando de los distintos modelos patentados y comercializados en Europa y Estados Unidos y de la expansión a nivel mundial del fotomatón.

Otras fuentes institucionales que se han consultado han sido los catálogos digitales de: la Hemeroteca del periódico ABC (http:/hemeroteca.abc.es); la 
Hemeroteca de La Vanguardia (http://www.lavanguardia.com/hemeroteca); y la Hemeroteca de la Biblioteca Nacional de España (http://www.bne.es/es/Catalogos/ HemerotecaDigital) en la que se han consultado las siguientes publicaciones periódicas en la fecha que se indica: La Época (1889), La Ilustración Ibérica (1897), El Globo (1897), La Iberia (1897-1898), La Correspondencia de España (1897), El Imparcial (1897), Blanco y Negro (1919), La Esfera (1928), Nuevo Mundo (1929), La Voz (1929), Estampa (1929), El Heraldo de Madrid (1929), La Libertad (1929), Revista ilustrada de banca, ferrocarriles, industria y seguros (1931), Ondas (1932) Las palabras clave empleadas en la búsqueda han sido: fotografía automática, fotodin, photomaton, fotomatón, Bosco Apolo, Bosco Pórtico Apolo, Bosco Teatro Apolo, L'Electra, restringiéndose la misma al periodo cronológico que atañe a la investigación, esto es, a los años comprendidos entre 1888 y 1929. Los resultados obtenidos fueron de gran interés permitiendo, entre otras cuestiones, conectar nombres de inventores con empresas, definir fechas y observar la reacción de la población ante la llegada del fotomatón a España.

Para la lista y el estudio de patentes en España han sido de gran interés las bases de datos del Archivo Histórico de la Oficina Española de Patentes y Marcas (http://historico.oepm.es). Por último, a la hora de definir conceptos como el de fotomatón, se ha empleado el recurso online del Diccionario de la lengua española (http://www.rae.es).

\subsection{DEFINICIÓN DE FOTOMATÓN}

Para comenzar es necesario establecer qué se entiende en este artículo por fotomatón. "Cabina equipada para hacer pequeñas fotografías en pocos minutos". La definición recogida en el Diccionario de la Lengua Española resulta incompleta e inexacta para esta investigación y es conveniente matizarla. Un fotomatón es, a efectos de este trabajo, un aparato que se acciona por medio de la introducción de una ficha o una moneda por una ranura dispuesta a tal efecto y que realiza de manera automática y autónoma todas las operaciones necesarias de toma, revelado, fijado, lavado y secado que se requieren para posteriormente entregar una o varias fotografias al cliente con su retrato.

Quedan excluidos, por tanto, aquellos dispositivos que requieran de la acción humana aunque, como se verá más adelante, en un estadio inicial de la técnica, el fotomatón precisaba de la asistencia de trabajadores que además de ayudar a unos clientes que desconocían el procedimiento se encargaban de reparar las máquinas cuando estas se estropeaban, algo que sucedía con cierta frecuencia según las crónicas de la época.

Tampoco son propiamente fotomatones los aparatos de fotografía automática que, aún funcionando sin asistencia humana, no producen fotografías sobre papel, es decir, que entregan al cliente ferrotipos, un procedimiento que consistía en un positivo directo sobre una lámina de metal recubierta con laca o esmalte oscuro sobre la que se colocaba la emulsión. No obstante, en este caso, la relación entre 
fotomatón y ferrotipos automáticos es muy clara y puede considerarse a estos aparatos como un claro precedente.

\subsection{CONTEXTO}

En los años veinte, en Europa y en Estados Unidos, la fotografía comenzaba a ser considerada por parte de los primeros movimientos de vanguardia un medio artístico de grandes posibilidades a nivel creativo y social. De manera paralela la industria fotográfica va desarrollándose con la intención de hacer accesible el medio a un público cada vez más amplio. En este sentido, cabe destacar un acontecimiento que haría que la fotografía traspasase la frontera del hogar: el lanzamiento en 1900 de las Kodak Brownie. Se popularizaba en ese momento la fotografía amateur bajo el eslogan You Press the Button, We Do the Rest. En este contexto de avances técnicos destinados a la democratización definitiva de la fotografía hay que situar el fenómeno del fotomatón.

\subsection{LA FOTOGRAFÍA AUTOMÁTICA: DEL FERROTIPO A LA TIRA DE PAPEL}

Si fue posible que a partir de 1927 se crease una industria del fotomatón a nivel mundial fue gracias a un proceso de treinta años de experimentación que culminó con la implantación de estudios Photomaton en América, Europa, África y Asia y con la creación de máquinas y empresas alternativas a este aparato con resultados comerciales más o menos favorables.

En 1883 Percival Everitt patentó la primera máquina expendedora viable a nivel comercial. Este invento, que a priori parece irrelevante para el mundo de la fotografía, será el germen de una revolución en la industria fotográfica que llega prácticamente hasta la era digital. Su idea de construir un aparato que por la acción de una moneda, encargada de activar el mecanismo de la máquina, entregase al cliente un producto sin que en todo el proceso fuera necesaria la intervención humana fue extrapolada al mundo de las cámaras fotográficas. De este modo los ferrotipistas comenzaron a construir cámaras de fotografía automática que en cualquier caso aún precisaban de la acción del hombre. Las más conocidas eran: Photographic Automaton, de Ferrer (1895, Francia); Auto-Photo, de Matthew Steffen (1889, Inglaterra); Photoscope (década de 1890, Estados Unidos); Bosco Automat, de Conrad Bernitt (década de 1890, Alemania); y General Electric CoinOp Photo Machine (1915, Estados Unidos). (Goranin, 2008: 39-41).

Uno de los primeros en intentar construir una máquina de fotografía automática que en lugar de producir ferrotipos creara imágenes fotográficas positivas sobre papel fue el estadounidense George N. Piper. Junto con su socio, Leo Stern, formó la Speedtype Operating Company para comercializar su invento. Pero, pese a autoproclamarse automáticos, estos aparatos requerían un asistente. 
Finalmente fue Josepho quien, en 1925, dio con la fórmula perfecta y tras años de intentos fallidos al fin una máquina, mediante la simple inserción de una ficha, era capaz de realizar automática e instantáneamente fotografías sobre papel. La patente de su aparato fue comprada por Henry Morganthau, antiguo embajador de Turquía y uno de los fundadores de la Cruz Roja americana, cuya intención era, según sus propias palabras, "hacer la fotografía personal fácil , barata y accesible para las masas de este país y hacer en el terreno fotográfico (...) lo que Ford había conseguido en el sector automovilístico" (Hines, 2002: 12). Morganthau comercializó el aparato con gran éxito en América. En lo que respecta a Europa, los derechos de la patente fueron cedidos por Josepho a un consorcio y el Photomaton empezó así su expansión mundial (Goranin, 2009: 21-23).

En Canadá, un joven inventor llamado David A. McCowan, fascinado por el reciente invento de Josepho, decidió crear su propia versión del fotomatón, adaptándolo al gusto local. Su aparato, de dimensiones más reducidas, se llamó Phototeria y las fotografías que realizaba, a diferencia de lo que sucedía con el dispositivo de Josepho, eran circulares en lugar de cuadradas. En 1927, McCowan colocó por vez primera varias máquinas en pequeñas ciudades de Ontario para comprobar la reacción del público, que como era de esperar, fue positiva. La patente fue posteriormente cedida a la empresa canadiense The National Automatic Machines Company que cambió el nombre del aparato por el de Photette. El modelo inicial de McGowan, que consistía fue ligeramente modificado, la madera fue sustituida por una estructura metálica y las puertas suprimidas en favor de una cortina. Esta máquina podía realizar cuatro fotografías de formato circular en un minuto (Goranin, 2009: 34-37).

Pronto empezaron a salirles competencia a los inventos de Josepho y McCowan. En 1931 había en Estados Unidos los siguientes modelos de fotomatón: Auto-Photo-Dome, Photo-Weigh Machine y Roovers Brothers Incorporated of Brooklyn en Nueva York; Automatic Photo Machine en Rochester; American Phototure Company of Dover y Automatic Film Machine Company of Wilmington en Delaware; Tru-Photo Machine; the Photola; Photosnap Inc. La mayoría de estos aparatos eran copias o falsificaciones del de Josepho, lo cual hizo que en muchas ocasiones se emprendieran acciones legales por plagio. No obstante, ninguna de las máquinas citadas tuvo el éxito comercial del que gozó el Photomaton y la mayoría solo estuvieron activas unos pocos años (Goranin, 2009: 37-38).

\subsection{LA REPRESENTACIÓN SOCIAL: EL RETRATO}

El fotomatón está pensando para que un individuo se haga un retrato. Todo en su diseño gira en torno a esta idea: la butaca, el reducido espacio, el encuadre y la 
iluminación artificial. No obstante, desde sus inicios, y vinculado a su carácter festivo, el fotomatón fue testigo de la amistad, el amor y el deseo ${ }^{1}$. Grupos de jóvenes, parejas [Anexo 5.1. Figura 1], padres e hijos [Anexo 5.1. Figura 2], todos se retrataban de manera conjunta en la intimidad que ofrece la cabina de fotomatón, apretándose con el fin salir en la foto. Los retratos no eran siempre de medio cuerpo, aunque esto era lo más habitual. También se construyeron cabinas que permitían al retratado posar de cuerpo entero ya fuera sentado [Anexo 5.1. Figura 3] de pie [Anexo 5.1. Figura 4], o realizando alguna actividad generalmente divertida o graciosa [Anexo 5.1. Figuras 5 y 6]. Las posibilidades a la hora de posar se multiplicaban en este tipo de fotomatones, convirtiéndose las tiras en una suerte de fotogramas en los que la acción se va sucediendo de una imagen a otra [Anexo 5.1. Figuras 7 y 8].

La escenografía del retrato de fotomatón se limita al fondo, que puede tener un paisaje pintado creando una ambientación determinada [Anexo 5.1. Figura 9], una tela con motivos decorativos geométricos o vegetales [Anexo 5.1. Figura 10], puede ser blanco, dejando que sea el rostro del cliente lo que destaque [Anexo 5.1. Figura 11] o puede ser una cortina que genere profundidad [Anexo 5.1. Figura 12]. Además de estos elementos cuya única función era embellecer un producto que, por otro lado, era bastante tosco -sobre todo si se compara con un retrato de estudio-, en ocasiones se realizaban ampliaciones de estas fotografias e incluso se pintaban a mano por artistas contratados a tal efecto [Anexo 5.1 Figura 13]. Las fotos de fotomatón eran rápidas, permitían al cliente adoptar diferentes poses y además el aparato funcionaba de manera automática sin que tras la cámara se escondiera la mirada de un fotógrafo indiscreto. No obstante, frente a los aspectos positivos, también estas máquinas contaban con carencias, especialmente en lo que a la técnica fotográfica se refiere. En un primer momento el retratado no podía moverse demasiado durante las sucesivas tomas porque corría el riesgo de que la imagen no saliese completamente congelada [Anexo 5.1. Figuras 14 y 15]. Además la profundidad de campo era muy limitada, por lo que si el cliente no se colocaba en un punto exacto, su retrato quedaba desenfocado [Anexo 5.1. Figuras 16 y 17].

La iluminación también era problemática, puesto que al no existir operador, tenía que utilizarse un esquema de luces estándar que no siempre daba buenos resultados técnicamente hablando. Pero todos estos defectos, lejos de perjudicar al fotomatón contribuyeron a configurar una estética desenfadada y lúdica acorde con el espíritu festivo que emana de estas fotografías. De este modo, aunque los errores técnicos fueran un problema para las fotos de carácter oficial, resultaban en cierta manera

${ }^{1}$ La fascinación general que existe por el fotomatón está estrechamente relacionada con el concepto lacaniano de "extimidad", esto es, el deseo -tan extendido en la sociedad occidentalde exhibir públicamente la intimidad. Precisamente por ser una suerte de confesionario, un espacio privado inserto en un lugar público, el fotomatón constituye el medio perfecto para explorar este tema, como así lo demostraron artistas como Franco Vaccari o Bruno Richard (Chéroux, 2012: 31). 
interesantes y atractivos en los retratos informales y, como ha sucedido tantas veces a lo largo de la historia, fueron asumidos posteriormente por la fotografía artística.

\subsection{USOS DEL FOTOMATÓN: DEL OCIO A LA IDENTIFICACIÓN}

No es tan fácil como a priori pudiera parecer establecer para qué fue inventado el fotomatón, cuál fue su función inicial y qué motivó su desarrollo y comercialización. Según Anatol Josepho, al que ya se ha señalado como inventor del fotomatón "oficial", su ambición no era otra que la de abaratar la fotografía consiguiendo con ello que todo el mundo tuviera acceso al retrato fotográfico. Este deseo democratizador parece, en efecto, uno de los motores que impulsaron la industria de la fotografía automática. El nuevo invento no sólo era asequible para las clases bajas sino que permitía a los clientes tomarse varias fotografías cambiando de pose lo cual hacía de esta máquina un juego. En los inicios de la fotografía automática, siempre que la prensa hace referencia al fotomatón resalta su aspecto lúdico. Además no hay olvidar que los primeros aparatos de fotografía automática se colocaron en ferias y centros recreativos. Una peculiaridad más hace especial al fotomatón, su automaticidad. El hecho de que no haya nadie tras la cámara que pueda juzgar al cliente, le otorga a éste absoluta libertad para gesticular sin pudor y poner las muecas que considere oportuno, con lo que se incide de nuevo en lo que de lúdico tenía y sigue teniendo retratarse en un fotomatón.

Ahora bien, algunos expertos consideran que esta industria no pudo generarse exclusivamente motivada por una supuesta demanda de retratos fotográficos a precios asequibles por parte de las clases más desfavorecidas ni por las posibilidades del fotomatón como aparato de recreo, y que si se invirtió tanto esfuerzo y dinero en el desarrollo de este tipo de fotografía se hizo en relación a la identificación. Es el caso de Ilsen About, que plantea en Identités automatiques: Le Photomaton et l'encartement des individus cómo el nacimiento del fotomatón y del concepto de fotografía como documento de identidad coinciden en el tiempo y están estrechamente vinculados. Aunque la fotografía ya era utilizada en los años cincuenta y sesenta del siglo XIX como medio de identificación personal, lo cierto es que fue en la década de 1880, momento en el que se pusieron en marcha las primeras máquinas de fotografía automática, cuando surgió el concepto de retrato judicial (About, 2012: 264). Solo por poner un ejemplo: en 1880, el archivo de Scotland Yard contaba con más de 14.000 retratos de presos en el Reino Unido (Sánchez Vigil y Fernández Fuentes, 2005: 191).

La fotografía, a pesar de reproducir "objetivamente" los rasgos del sujeto, era un medio impreciso de identificación personal en comparación con otras técnicas científicas de biometría utilizadas en aquella época como la dactiloscopia o la antropometría. Sin embargo su uso se fue imponiendo poco a poco de tal modo que a finales de 1880, al tiempo que Edwin Ball en Gran Bretaña, Juan Cantó en España y Théophile Enjalbert en Francia muestran al público sus máquinas de fotografía automática en las Exposiciones Universales, la policía está llevando a cabo 
importantes progresos en el campo de la identificación, creando un protocolo para la producción en masa de retratos fotográficos. De este modo, en la Exposición Universal de París de 1889, mientras Enjalbert enseña a un público maravillado su aparato fotográfico automático, Alphonse Bertillon ilustra los métodos de identificación empleados en la prefectura de policía en los que combina fotografía con antropometría (Sánchez Vigil y Fernández Fuentes, 2005: 192). El potencial de los precedentes de lo que hoy conocemos como fotomatón no pasa inadvertido a ciertos espectadores que comentan: “ (...) hay todo un campo nuevo de estudios, sobre todo en nuestra época, donde el retrato fotográfico tiende cada vez más a reemplazar a los antiguos métodos de reconocimiento" (About, 2012: 266).

En un primer momento las fotografías de fotomatón fueron vistas con desconfianza por parte de las autoridades, por el hecho de que se pudiera cambiar de pose entre una toma y otra. Así, el 17 de abril de 1930 podía leerse en $L a$ Vanguardia lo que sigue:

Advertimos a los señores peregrinos que para el pasaporte colectivo deben presentar dos fotografías iguales de $3 \times 4$ centímetros (más o menos), con su nombre en el reverso y la cédula personal. Tengan presente que en la delegación de policía se rechazan las fotografías del Fotomatón por ser cambiables las caras y no ser iguales a las otras (La Vanguardia, 17/04/1930).

Incluso en 1949, el fotomatón sigue siendo rechazado por las autoridades, en esta ocasión por una supuesta dificultad a la hora de identificar al sujeto de la fotografía:

Con respecto a la nueva tarjeta militar que debe solicitarse a cambio de la actual, que ya caduca, el ministro del Ejército ha comunicado al capitán general que las fotografias para la nueva tarjeta dispuesta por Orden del 8 de febrero último (D. O. Número 32), deben ser sobre fondo blanco, pues la de fondo negro y las de sistema rápido conocido por 'fotomatón' hacen que la identificación de la persona resulte imposible para la reproducción en la tarjeta. Es preciso que las fotografias estén hechas por procedimientos más perfectos... (La Vanguardia, 05/04/1949).

Aunque es cierto que el fotomatón no ofrecía, en los primeros años de su puesta en marcha, la misma calidad que se podía conseguir yendo a un estudio de fotografía, el que se prohibiera su uso en los documentos oficiales puede tener relación con presiones ejercidas por parte de los fotógrafos, que veían peligrar su trabajo con la llegada de los nuevos aparatos automáticos. No obstante, pese a todos los esfuerzos del gremio, el fotomatón acabaría imponiéndose como máquina ideal para la denominada foto de carnet, estableciéndose, eso sí, normas 
estrictas con respecto a la pose, la colocación, el fondo y demás elementos que conforman la imagen con el fin de otorgarle un carácter oficial.

En España la fotografía no fue incorporada al carnet de identidad hasta 1946 (Sánchez Vigil y Fernández Fuentes, 2005: 193) y ya a partir de los años 50 comienzan a aparecer anuncios en la prensa relativos ahora a la idoneidad del fotomatón para realizar la fotografías requerida para el documento nacional de identidad. El 27 de mayo de 1951 salía en La Vanguardia el siguiente anuncio:

La acreditada Casa PHOTOMATON comunica al público que en sus establecimientos PHOTOMATON se han instalado los aparatos fotográficos adecuados para las fotos de modelo oficial, con los cuales será usted bien atendido y recibirá un trabajo perfecto en pocos minutos a precio económico (La Vanguardia, 27/05/1951).

Como vemos, si el fotomatón empezó como un juego, se vieron desde muy temprano sus posibilidades de servir al Estado en su deseo de garantizar el orden público y asegurar el funcionamiento de las instituciones y las empresas, en un esfuerzo, en definitiva, por tener controlados a sus ciudadanos. La "libertad" inherente a la cabina de fotomatón sirvió para atenuar las posibles reticencias de la gente a entregar su imagen para satisfacer los imperativos de identificación del aparato del Estado. El aspecto lúdico del fotomatón hizo además que el hecho de retratarse, aunque fuera con el propósito de obtener una imagen oficial, se convirtiera en una actividad intrascendente e incluso frívola (About, 2012: 270).

\section{EL FOTOMATÓN EN ESPAÑA}

\subsection{CRONOLOGÍA}

En la tabla I se recogen en orden cronológico los principales acontecimientos en torno a los inicios del fotomatón en España y a nivel internacional, lo que permite realizar una comparativa. Se han establecido dos campos, el primero de ellos con el año, y el segundo con la información y la fuente de la misma, incluyendo cuando se conoce, además el día y el mes.

Tabla I. Cronología del fotomatón

Fuente: elaboración propia

\begin{tabular}{|l|l|}
\hline $\mathbf{1 8 6 0}$ & $\begin{array}{l}\text { Se populariza el ferrotipo (colodión sobre placa metálica ennegrecida) en Estados } \\
\text { Unidos. Este procedimiento permitía obtener una imagen fotográfica única disponible } \\
\text { poco tiempo después de la toma fotográfica, pero no ofrecía la multiplicidad ni el soporte } \\
\text { en papel propios del fotomatón (Frizot, 1994: 504) }\end{array}$ \\
\hline $\mathbf{1 8 8 3}$ & $\begin{array}{l}\text { Percival Everett inventa la primera máquina expendedora viable desde un punto de vista } \\
\text { comercial }\end{array}$ \\
\hline $\mathbf{1 8 8 7}$ & Le es concedida al británico Edwin J. Ball la primera patente de una máquina de \\
\hline
\end{tabular}




\begin{tabular}{|c|c|}
\hline & fotografía automática por su "automatic coin-freed apparatus" \\
\hline 1888 & $\begin{array}{l}\text { 18/02. Juan Cantó y Mas patenta el primer aparato de fotografía automática en España, } \\
\text { "una máquina llamada Báscula fotográfica automática con la cual al sentarse un individuo } \\
\text { cualquiera en su silla quedará retratado por medio de la fotografía y en el mismo instante } \\
\text { le será entregado el retrato" y lo presenta en la Exposición Universal de Barcelona }\end{array}$ \\
\hline 1892 & $\begin{array}{l}\text { Se instalan en Barcelona los primeros aparatos de fotografía automática precedentes del } \\
\text { fotomatón patentados y explotados por Antonio Durán y Fornel }\end{array}$ \\
\hline 1893 & $\begin{array}{l}\text { Se constituye la Sociedad Auto-fotográfica SA en Barcelona para dedicarse a la } \\
\text { construcción, explotación y venta de un sistema de máquina o aparato denominado } \\
\text { "máquina auto-fotográfica" }\end{array}$ \\
\hline 1897 & $\begin{array}{l}\text { Llega a Madrid la máquina Bosco, anunciada en la prensa como una maravilla fotográfica. } \\
\text { Este aparato había sido patentado por Conrad Bernitt en } 1890 \text { (Gosio y Chiesa, 2013) y } \\
\text { tuvo cierto éxito comercial en Europa. En Madrid se colocó en el Pórtico del Teatro } \\
\text { Apolo, y al parecer gozó de cierto éxito: "Hemos tenido el gusto de ver el nuevo aparato } \\
\text { 'Bosco', que da una fotografía por el precio de una peseta, hecha en tres minutos. Este } \\
\text { aparato está colocado en el Pórtico de Apolo, donde está siendo muy visitado" (El Globo, } \\
27 / 11 / 1897)\end{array}$ \\
\hline 1913 & $\begin{array}{l}\text { 17/07. La Sociedad Auto-fotográfica SA queda disuelta por transcurso del plazo de } \\
\text { duración }\end{array}$ \\
\hline 1925 & $\begin{array}{l}\text { El siberiano Anatol Josepho patenta el fotomatón, la primera máquina automática en } \\
\text { conseguir realizar positivos directos sobre papel, y abre en septiembre el primer estudio } \\
\text { Photomaton en Broadway, entre las calles } 51 \text { y } 52 \text { (Goranin, 2008: 21) }\end{array}$ \\
\hline 1926 & $\begin{array}{l}\text { Henry Morganthau ofrece a Josepho un millón de dólares por los derechos de } \\
\text { explotación del fotomatón en América. La prensa de la época se hace eco de la noticia. } \\
\text { Puede leerse en el New York Times lo que sigue: "Slot Photo Device Brings } \$ 1,000,000 \\
\text { to Young Inventor" (Goranin, 2008: 22) }\end{array}$ \\
\hline 1927 & $\begin{array}{l}\text { Se crea la Sociedad Photomaton Parent Corporation Ltd. en noviembre de 1927. Esta } \\
\text { sociedad tiene los derechos del fotomatón en Gran Bretaña, Francia, Alemania, Italia y } \\
\text { Canadá (Frizot, 1994: 504) }\end{array}$ \\
\hline 1928 & $\begin{array}{l}\text { Se instalan las cinco primeras cabinas de Photomaton en París (Galerías Lafayette, } \\
\text { Sam's, Petit-Journal, Luna Park y Jardín d'Acclimatation) (Frizot, 1994: 504) } \\
\text { 06/11. Se firma un contrato entre Photomaton Parent Corporation Ltd. y la Sociedad } \\
\text { Anónima Photomaton "La Fotografía Perfecta" en el que se establece que la compañia } \\
\text { española obtiene el derecho de explotar industrialmente en España, Portugal y sus } \\
\text { Colonias las máquinas objeto de la patente de invención por veinte años número } 95.294 \\
\text { "Mejoras en aparato fotográfico automático" expedida originalmente a favor de Anatol } \\
\text { Marco Josepho }\end{array}$ \\
\hline 1929 & $\begin{array}{l}\text { 17/02. El Photomaton llega a Barcelona y se instala en la calle Pelayo } 56 \text { ( } L a \\
\text { Vanguardia, 16/02/1929 y 07/04/1929). } \\
\text { 30/03. Se inaugura en Madrid la fotografía automática Photomaton con un local en la } \\
\text { calle Arlabán esquina con Sevilla. El artista fotógrafo Miguel Andrés era el encargado } \\
\text { de las ampliaciones artísticas (Estampa, 09/04/1929; El Sol, 30/03/1929) } \\
\text { 03/06. Se constituye la Sociedad Española de Fotografía Automática en Madrid para } \\
\text { dedicarse a la explotación, venta y alquiler de aparatos automáticos o semi-automáticos } \\
\text { de fotografía patentados por la entidad Poso-Graph Corporation Ltd. de Londres. El } 4 \text { de } \\
\text { junio se anuncia la llegada de FOTODIN a España "Una potente Sociedad inglesa ha }\end{array}$ \\
\hline
\end{tabular}




\begin{tabular}{|c|c|}
\hline & $\begin{array}{l}\text { lanzado un maravilloso aparato fotográfico que obtiene actualmente un gran éxito, y, } \\
\text { aunque en España estamos acostumbrados a conocer con gran retraso los adelantos } \\
\text { europeos, ahora no va a ser así: Madrid será una de las primeras capitales que conozcan } \\
\text { el FOTODIN, porque se ha constituido una importante empresa que va a propagar por } \\
\text { España este invento. Como nuestros lectores ven por las fotografías que publicamos, } \\
\text { varias populares personalidades se han retratado ya en estos maravillosos aparatos, que, } \\
\text { gracias a la Sociedad Española de Fotografía Automática, estarán dentro de unos días al } \\
\text { servicio de nuestros paisanos" (Estampa, 04/06/1929) } \\
\text { La prensa nacional recoge la noticia de la quiebra del grupo Hatry en septiembre de } \\
1929 \text { (factor que contribuyó al denominado Crack del 29). Dentro de las Sociedades } \\
\text { afectadas por el derrumbamiento se incluye la Photomaton Parent Corporation, Ltd. (El } \\
\text { Sol, 01/10/1929; La Ilustración Financiera, 02/10/1929; Revista Ilustrada de banca, } \\
\text { ferrocarriles, industria y seguros, 10/10/1929) }\end{array}$ \\
\hline 1932 & $\begin{array}{l}\text { 10/01. Se declaró caducada la concesión de la patente } 95.294 \text { a la Sociedad Anónima } \\
\text { Photomaton "La Fotografía Perfecta" por no haberse satisfecho los derechos } \\
\text { correspondientes a la séptima anualidad }\end{array}$ \\
\hline 1933 & $\begin{array}{l}\text { Este año hay instalados } 140 \text { estudios Photomaton en Francia y } 240 \text { en Estados Unidos } \\
\text { (Frizot, 1994: 504) }\end{array}$ \\
\hline 1939 & $\begin{array}{l}\text { La Sociedad Anónima Photomaton "La Fotografía Perfecta" solicita hacerse cargo de } \\
\text { abonar directamente todas las cuotas y demás gastos en que haya podido incurrir dicha } \\
\text { patente para que pueda ser de nuevo puesta en vigor por los años que le quedan de vida }\end{array}$ \\
\hline 1946 & $\begin{array}{l}\text { La fotografía se incorpora al carnet de identidad (Sánchez Vigil y Fernández Fuentes, } \\
\text { 2005: 193) }\end{array}$ \\
\hline
\end{tabular}

\subsection{PATENTES DE INVENCIÓN Y DE INTRODUCCIÓN (1888-1929)}

Tabla II. Patentes de invención e introducción

Fuente: elaboración propia

\begin{tabular}{|c|l|l|l|l|l|}
\hline $\begin{array}{c}\text { NÚMERO } \\
\text { PATENTE }\end{array}$ & \multicolumn{1}{|c|}{ TÍTULO } & SOLICITANTE & \multicolumn{1}{|c|}{$\begin{array}{c}\text { FECHA } \\
\text { CONCESIÓN }\end{array}$} & $\begin{array}{c}\text { PUESTA } \\
\text { EN } \\
\text { PRÁCTICA }\end{array}$ & CIUDAD \\
\hline 7510 & $\begin{array}{l}\text { Una máquina llamada } \\
\text { Báscula fotográfica } \\
\text { automática con la cual } \\
\text { al sentarse un individuo } \\
\text { cualquiera en su silla } \\
\text { quedará retratado por } \\
\text { medio de la fotografía y } \\
\text { en el mismo instante le } \\
\text { será entregado el retrato }\end{array}$ & $\begin{array}{l}\text { Cantó Mas, } \\
\text { Juan }\end{array}$ & $\mathbf{1 8 8 8} / 02 / 18$ & No & Barcelona \\
\hline 9986 & $\begin{array}{l}\text { Aparato fotográfico } \\
\text { automático }\end{array}$ & $\begin{array}{l}\text { Enjalbert, } \\
\text { Théophile } \\
\text { Ernest }\end{array}$ & $\mathbf{1 8 8 9} / 10 / 14$ & No & París \\
\hline 10501 & $\begin{array}{l}\text { Máquina automática } \\
\text { para la obtención de } \\
\text { fotografías }\end{array}$ & $\begin{array}{l}\text { Martí Biosca, } \\
\text { Federico }\end{array}$ & $\mathbf{1 8 9 0} / 03 / 07$ & No & Barcelona \\
\hline 10758 & Mejoras en la & Durán Fornel, & $\mathbf{1 8 9 0} / 06 / 03$ & Sí & Madrid \\
\hline
\end{tabular}




\begin{tabular}{|c|c|c|c|c|c|}
\hline $\begin{array}{l}\text { NÚMERO } \\
\text { PATENTE }\end{array}$ & TÍTULO & SOLICITANTE & $\begin{array}{c}\text { FECHA } \\
\text { CONCESIÓN }\end{array}$ & $\begin{array}{c}\text { PUESTA } \\
\text { EN } \\
\text { PRÁCTICA }\end{array}$ & CIUDAD \\
\hline & $\begin{array}{l}\text { construcción de los } \\
\text { aparatos puestos en } \\
\text { acción por la inserción } \\
\text { de moneda para } \\
\text { fotografiar } \\
\text { automáticamente las } \\
\text { personas y los objetos y } \\
\text { para exhibir y entregar } \\
\text { las referidas fotografías }\end{array}$ & Antonio & & $\begin{array}{l}\text { 1892/07/29 } \\
\text { Caducó el } \\
1896 / 03 / 02 \\
\text { Causas: } \\
\text { fenecimient } \\
\text { o }\end{array}$ & \\
\hline 11369 & $\begin{array}{l}\text { Aparato perfeccionado } \\
\text { para sacar y acabar } \\
\text { automáticamente } \\
\text { fotografías }\end{array}$ & $\begin{array}{l}\text { Ramspeck, Karl } \\
\text { / Schäfer, } \\
\text { Barthold / } \\
\text { Harms, } \\
\text { Christoph } \\
\end{array}$ & 1890/12/18 & No & Hamburgo \\
\hline 12649 & Un fotógrafo autómata & $\begin{array}{l}\text { Durán Fornel, } \\
\text { Antonio }\end{array}$ & 1891/11/20 & $\begin{array}{l}\text { Sí } \\
1894 / 01 / 18 \\
\text { Caducó el } \\
1901 / 06 / 11 \\
\text { Cedido el } \\
1899 / 02 / 11 \\
\end{array}$ & Madrid \\
\hline 13519 & $\begin{array}{l}\text { Un aparato fotográfico } \\
\text { automático }\end{array}$ & $\begin{array}{l}\text { Enjalbert, } \\
\text { Théophile } \\
\text { Ernest }\end{array}$ & 1892/07/26 & No & París \\
\hline 13540 & $\begin{array}{l}\text { Perfeccionamientos } \\
\text { introducidos en las } \\
\text { máquinas fotográficas } \\
\text { automáticas }\end{array}$ & $\begin{array}{l}\text { Cabanach, } \\
\text { Pedro / Güell, } \\
\text { Francisco / } \\
\text { Petit, Miguel / } \\
\text { Fábrega, Ramón } \\
\text { / Fábrega, } \\
\text { Marcelino / } \\
\text { Güell Bergés, } \\
\text { Juan }\end{array}$ & 1892/07/28 & $\begin{array}{l}\text { Sí } \\
1895 / 01 / 31 \\
\text { Caducó el } \\
1898 / 11 / 02\end{array}$ & Barcelona \\
\hline 13714 & $\begin{array}{l}\text { Mejoras en las } \\
\text { máquinas destinadas a } \\
\text { obtener } \\
\text { automáticamente } \\
\text { fotografías }\end{array}$ & $\begin{array}{l}\text { Sugrañes, } \\
\text { Marcos }\end{array}$ & 1892/09/23 & No & Barcelona \\
\hline 14776 & $\begin{array}{l}\text { Una máquina } \\
\text { autofotográfica } \\
\text { destinada a la } \\
\text { producción automática } \\
\text { de fotografías }\end{array}$ & $\begin{array}{l}\text { Sociedad } \\
\text { Autofotográfica }\end{array}$ & 1893/09/07 & $\begin{array}{l}\text { Sí } \\
1895 / 11 / 04 \\
\text { Caducó el } \\
1898 / 11 / 02\end{array}$ & Barcelona \\
\hline 16748 & $\begin{array}{l}\text { Un aparato de fotografía } \\
\text { automático }\end{array}$ & $\begin{array}{l}\text { André \& } \\
\text { Lieutier / } \\
\text { Girandy, Guiton } \\
\text { de } \\
\end{array}$ & 1895/01/21 & No & Marsella \\
\hline 23011 & $\begin{array}{l}\text { Un aparato de fotografía } \\
\text { autómata perfeccionado }\end{array}$ & $\begin{array}{l}\text { Durán Fornel, } \\
\text { Antonio / } \\
\text { Hernando Ruiz, }\end{array}$ & 1898/09/05 & No & Madrid \\
\hline
\end{tabular}




\begin{tabular}{|c|c|c|c|c|c|}
\hline $\begin{array}{l}\text { NÚMERO } \\
\text { PATENTE }\end{array}$ & TÍTULO & SOLICITANTE & $\begin{array}{c}\text { FECHA } \\
\text { CONCESIÓN }\end{array}$ & $\begin{array}{c}\text { PUESTA } \\
\text { EN } \\
\text { PRÁCTICA }\end{array}$ & CIUDAD \\
\hline & & $\begin{array}{l}\text { Mariano / Díez } \\
\text { González, Pedro }\end{array}$ & & & \\
\hline 25273 & $\begin{array}{l}\text { Un aparato automático e } \\
\text { instantáneo para } \\
\text { producir fotografías }\end{array}$ & $\begin{array}{l}\text { Romani, } \\
\text { François de } \\
\text { Paula }\end{array}$ & 1900/01/13 & No & Lyon \\
\hline 27440 & $\begin{array}{l}\text { Un aparato fotográfico } \\
\text { automático. }\end{array}$ & $\begin{array}{l}\text { Calvet, Emilio } \\
\text { Antón }\end{array}$ & $1901 / 03 / 30$ & No & Barcelona \\
\hline 30118 & $\begin{array}{l}\text { Un aparato automático } \\
\text { que mediante una } \\
\text { moneda produce } \\
\text { retratos fotográficos. }\end{array}$ & $\begin{array}{l}\text { Pifer, George } \\
\text { Nicholas }\end{array}$ & 1902/08/12 & No & Cleveland \\
\hline 46312 & $\begin{array}{l}\text { Aparato automático de } \\
\text { fotografía sobre papel o } \\
\text { tarjeta postal }\end{array}$ & $\begin{array}{l}\text { Wolff, Harry } \\
\text { Ashton }\end{array}$ & 1909/11/06 & No & $\begin{array}{l}\text { Courbevoi } \\
\text { e }\end{array}$ \\
\hline 49584 & $\begin{array}{l}\text { Un aparato fotográfico } \\
\text { automático }\end{array}$ & $\begin{array}{l}\text { Baradat Guillé, } \\
\text { Claudio / } \\
\text { Bosch, } \\
\text { Francisco }\end{array}$ & 1911/01/07 & $\begin{array}{l}\text { Sí } \\
\text { 1914/02/25 } \\
\text { Caducó el } \\
\text { 1922/01/01 }\end{array}$ & Barcelona \\
\hline 86070 & $\begin{array}{l}\text { Perfeccionamientos en } \\
\text { máquinas fotográficas } \\
\text { que funcionan } \\
\text { automáticamente, } \\
\text { mediante la inserción de } \\
\text { una moneda o a mano }\end{array}$ & $\begin{array}{l}\text { Bailey, Ernest } \\
\text { Frederick }\end{array}$ & 1923/08/11 & No & Londres \\
\hline 95294 & $\begin{array}{l}\text { Mejoras en aparato } \\
\text { fotográfico automático }\end{array}$ & $\begin{array}{l}\text { Josepho, Anatol } \\
\text { Marco }\end{array}$ & $1925 / 12 / 16$ & $\begin{array}{l}\text { No. Cedida } \\
\text { el } \\
1928 / 09 / 03\end{array}$ & $\begin{array}{l}\text { Nueva } \\
\text { York }\end{array}$ \\
\hline 109159 & $\begin{array}{l}\text { Perfeccionamientos en } \\
\text { los aparatos } \\
\text { fotográficos } \\
\text { automáticos }\end{array}$ & $\begin{array}{l}\text { Photomaton } \\
\text { Parent } \\
\text { Corporation } \\
\text { Ltd. } \\
\end{array}$ & 1928/09/12 & No & Londres \\
\hline 108593 & $\begin{array}{l}\text { Mejoras en las cámaras } \\
\text { y aparatos fotográficos } \\
\text { que funcionan mediante } \\
\text { la introducción de una } \\
\text { moneda }\end{array}$ & $\begin{array}{l}\text { Murray, Charles } \\
\text { Henry }\end{array}$ & 1928/11/30 & No & $\begin{array}{l}\text { Newcastle } \\
\text { upon Tyne }\end{array}$ \\
\hline 110427 & $\begin{array}{l}\text { Mejoras en o relativas a } \\
\text { aparatos fotográficos } \\
\text { automáticos o } \\
\text { semiautomáticos que } \\
\text { funcionan por moneda }\end{array}$ & $\begin{array}{l}\text { Hart, Stanley / } \\
\text { Stealey, James } \\
\text { Isaac }\end{array}$ & 1928/12/17 & No & Brighton \\
\hline 110662 & $\begin{array}{l}\text { Perfeccionamientos } \\
\text { introducidos en las } \\
\text { máquinas para } \\
\text { fotografiar } \\
\text { automáticamente } \\
\end{array}$ & $\begin{array}{l}\text { Berriatúa Cruz, } \\
\text { Julio }\end{array}$ & $1929 / 02 / 20$ & No & Madrid \\
\hline 113986 & $\begin{array}{l}\text { Un aparato fotográfico } \\
\text { automático }\end{array}$ & $\begin{array}{l}\text { Pérez Sáez, } \\
\text { Leonardo / } \\
\text { Nieto }\end{array}$ & $1929 / 07 / 27$ & $\begin{array}{l}\text { Sí } \\
\text { 1932/07/02 } \\
\text { Caducó el }\end{array}$ & Bilbao \\
\hline
\end{tabular}




\begin{tabular}{|l|l|l|l|l|l|}
\hline $\begin{array}{l}\text { NÚMERO } \\
\text { PATENTE }\end{array}$ & TÍTULO & SOLICITANTE & $\begin{array}{c}\text { FECHA } \\
\text { CONCESIÓN }\end{array}$ & $\begin{array}{c}\text { PUESTA } \\
\text { EN } \\
\text { PRÁCTICA }\end{array}$ & CIUDAD \\
\hline & & $\begin{array}{l}\text { Echebarrena, } \\
\text { Jaime }\end{array}$ & & $1944 / 07 / 02$ & \\
\hline
\end{tabular}

A finales de los años ochenta y especialmente en los noventa del siglo XIX fueron solicitadas numerosas patentes de invención concernientes a aparatos de fotografía automática. En esta carrera por conseguir la máquina perfecta capaz de realizar y entregar una fotografía de manera completamente automática y autónoma fueron muchos los inventores que lo intentaron y fracasaron. La mayor parte de las patentes que se van a mencionar aquí no pasaron del papel, y las que se pusieron en práctica no lograron estar en funcionamiento muchos años. La mayoría de estos aparatos se instalaron en Barcelona primero y luego en Madrid. Sin embargo las deficiencias técnicas que presentaban y que patente tras patente no pudieron ser solucionadas hasta entrada la segunda década del siglo XX hizo que la expansión y popularización de fotomatón no se produjese hasta ese momento.

La primera patente de este tipo de la que se tiene constancia le fue concedida al británico Edwin J. Ball el veintitrés de noviembre de 1887 por su automatic coinfreed apparatus. Ese mismo mes, en España, Juan Cantó y Mas, un fotógrafo e inventor catalán, solicitaba una patente de invención para una máquina de fotografía automática, que le sería concedida el dieciocho de febrero de 1888 [Anexo 5.2. Figura 1] . El aparato del catalán fue presentado ese mismo año en la Exposición Universal de Barcelona y es definido por el propio Cantó y Mas en la memoria descriptiva presentada en el registro del Ministerio de Fomento como:

Una máquina llamada Báscula fotográfica automática con la cual al sentarse un individuo cualquiera en su silla quedará retratado por medio de la fotografía y en el mismo instante le será entregado el retrato.

El nombre de báscula se debe a que además de retratar al cliente en cuestión, al sentarse éste en la silla giratoria prepara a tal efecto, también sería pesado.

Cantó señala además como referente la máquina expendedora de Everitt:

El ejemplo de las básculas sistema Evertitt que con tanto éxito funcionara y los puestos de venta automática de tarjetas postales (...) y otros artículos establecidos en varias Capitales de Europa, nos han hecho ver la posibilidad de inventar un medio, que de primer momento creíamos de difícil solución.

En este documento se insiste en la automaticidad y autonomía del proceso en el que la máquina lo hace todo sola, desde el momento de la toma hasta la entrega del producto perfectamente terminado, pasando por el revelado, el fijado y el secado: 
La perfección que alcanzan en nuestra época las artes mecánicas y las múltiples aplicaciones que de ellas se hacen, para lograr la automaticidad, en cuanto sea posible, de las diversas manipulaciones industriales, nos ha movido a estudiar un aparato que haga todas las operaciones de la fotografia, desde la impresión de la imagen, hasta la entrega de la prueba, de una manera completamente automática.

Solo unos meses más tarde, Ernest Théophile Enjalbert presentaba, en la Exposición Universal de París de 1889, su aparato fotográfico automático [Anexo 5.2. Figuras 2 y 3], que gozaría de cierto éxito comercial. En España dos medios de comunicación se hacían eco de la noticia: La Vanguardia (09/08/1889) y La Época (10/08/1889). El primero definía el aparato de Enjalbert como una "maravilla (...) Un aparato [que] está destinado a ejecutar todas las operaciones fotográficas necesarias para obtener el retrato del modelo que se coloca en un sillón puesto ad hoc, el cual, previamente, deposita una moneda en la caja". En La Época inciden sobre las semejanzas entre esta máquina y las balanzas automáticas, aspecto en el que este aparato coincide con el presentado por Cantó y Mas en la Exposición de Barcelona. Los dos periódicos apuntan la rapidez del procedimiento, señalando que desde el momento de la toma hasta la entrega de la fotografía solo pasan cinco minutos "tiempo que, como saben cuantos gusten de los asuntos fotográficos, no llega ni con mucho al que necesita un buen artista para preparar, fijar, hacer el lavado y secar las placas".

Las primeras máquinas fueron instaladas en el Jardin d'Acclimatation de París, pero las fotografías que se obtenían con este aparato eran aún de calidad mediocre y los aparatos se estropeaban con frecuencia. Esto, unido a un precio elevado y a un rápido deterioro del material fotográfico, hizo que el invento de Enjalbert no prosperase. En 1895 la revista La Nature hacía referencia al fracaso "de un aparato automático que entregaba por 50 céntimos $^{2}$ una pequeña placa en la que el retrato apenas podía ser visto y en el que la persona era normalmente irreconocible" (Pellicer, 2010: 16).

En 1890 le fue concedida la patente de invención a otro español, Federico Martí Biosca, por una "máquina automática para la obtención de fotografías" [Anexo 5.2. Figura 4]. En la correspondiente memoria descriptiva se lee lo que sigue:

Aún cuando de un par de años a esta parte se han hecho grandes esfuerzos para obtener una máquina fotográfica práctica, ni en

2 Según la prensa española de la época el precio inicial de 50 céntimos se descartó, fijándose finalmente en 10 céntimos, lo cual permitiría a "todo mortal" retratarse en uno de estos aparatos. En cualquier caso, aún con un precio reducido, lo cierto es que la calidad de estas fotografías dejaba bastante que desear y con el paso del tiempo terminaban deteriorándose. 
España ni el extranjero se ha logrado dar una solución verdadera y completa al problema.

La máquina objeto de la presente patente a la sencillez reúne la perfección de los movimientos ora sean los de simple mecanismo o bien los de procedimiento.

La máquina tiene por objeto impresionar, revelar y fijar una placa sensible en el momento oportuno. Para ello se fija como condición el que todos los mecanismos estén a punto de funcionar permaneciendo en reposo hasta que por la invención de un agente exterior sea una moneda medalla $u$ otro objeto provisto de verificar la impulsión necesaria para operar el movimiento.

En el documento, Martí Biosca se hace eco de la situación de la fotografía automática, confirmando que desde 1888 se están llevando a cabo intentos para conseguir un aparato capaz de realizar de manera autónoma y automática todas las operaciones que requiere la toma, revelado y entrega de una fotografía sin éxito. Según su inventor, esta nueva máquina vendría a subsanar los fallos de sus predecesoras gracias a una serie de modificaciones técnicas que aparecen perfectamente detalladas en la memoria descriptiva entregada con la solicitud de la patente $^{3}$. Con este aparato, por vez primera, podía utilizarse cualquier tipo de procedimiento fotográfico como el inventor mismo indica, a diferencia de otras máquinas que sólo producían ferrotipos:

Esta máquina tal como se ha descrito es completamente independientemente del sistema fotográfico que se emplee. Así pues lo mismo puede servir para placas preparadas al colodión que a la gelatina u otro cualquier medio de sensibilizarlas, pudiendo también emplearse cualquier sistema de líquidos o productos para el revelado, fijado, lavado reforzado u otra operación fotográfica.

También en 1890, otro español, Antonio Durán y Fornel, solicitaba una patente de invención por cinco años por "Mejoras en la construcción de los aparatos puestos en acción por la inserción de moneda para fotografiar automáticamente las personas y los objetos y para exhibir y entregar las referidas fotografías" [Anexo 5.2. Figura 5]. Esta es además la primera de las patentes de este tipo que se puso en práctica en España, en concreto el 29 de julio de 1892. De nuevo el procedimiento fotográfico utilizado por la máquina es la ferrotipia.

Tenemos constancia, a través de la prensa, de que estos aparatos se pusieron en

${ }^{3}$ Son los tecnicismos lo que diferencian uno documentos de otros, lo cual indica si el que presenta la solicitud es un fotógrafo o un ingeniero. En el caso de Biosca y de casi todos los solicitantes a partir de este momento se aprecia claramente un vocabulario especializado muy distinto por ejemplo del empleado por Juan Cantó y Más, fotógrafo de profesión. 
práctica. El 30 de junio de 1892, el ayuntamiento de Barcelona acordó "autorizar a don Antonio Durán y Fornel para la colocación de aparatos fotográficos automáticos en varios puntos de la ciudad" (La Vanguardia, 1 de julio de 1892). A principios del mes de noviembre:

Comenzarán a funcionar los kioskos que han sido levantados en la plaza de la Paz, de la Universidad y en la de la Pajarera de los jardines del Parque de esta ciudad, los cuales contienen los aparatos de las máquinas fotográficas automáticas. Por medio de este aparato y echando una moneda de diez céntimos se obtendrá el retrato en el término de media hora. (La Vanguardia, 27 de octubre de 1892).

Un año más tarde, el 20 de noviembre de 1891, se le concedió al mismo Durán y Fornel, una patente de invención por "un fotógrafo autómata" [Anexo 5.2. Figura 6]. Este curioso aparato, a diferencia del resto de máquinas, contaba con un aspecto antropomórfico. Según la descripción del mismo en la memoria presentada a la Oficina Internacional de Patentes, el autómata movía los ojos para indicar al cliente el momento en el que la máquina estaba disponible para su uso. Este autómata tenía incluso, según este documento, la capacidad de "hablar" mediante unos fonógrafos que indicaban al retratado cómo colocarse de manera adecuada.

Este fotógrafo autómata, por medio de unos ojos movibles podrá dar en aprobación a la persona que se ponga, y por la marcha intermitente de uno o varios fonógrafos por ejemplo podrá llamar a sus clientes, hacerles que se coloquen convenientemente, etc.

Pese a su aspecto futurista y poco funcional, el aparato de Durán y Fornel se puso en práctica por vez primera el 18 de enero de 1894 .

Con fecha de ayer ha sido firmada ante el notario de este ilustre colegio don Ignacio Jaumandréu, la escritura de sociedad para la explotación de las máquinas automáticas fotográficas denominadas "El fotógrafo autómata", cuya patente de invención le fue concedida por el Ministerio de Fomento el día 24 de noviembre último a don Antonio Durán y Fornel por el término de veinte años. El cargo de gerente ha sido confiado al conocido propietario de esta ciudad, don Augusto Soler y Monés. (La Vanguardia (29/03/1892).

El viernes 8 de diciembre de 1905 La Vanguardia anuncia que:

El Ayuntamiento (...) por acuerdo adoptado en sesión, ha declarado caducada la concesión que otorgó a favor de don Antonio Durán y Fornel para explotar en distintos sitios públicos de esta capital el aparato de su 
invención denominado: 'Un fotógrafo autómata', debiendo desaparecer, a expensas del concesionario, los aparatos subsistentes dentro del plazo de quince días. (La Vanguardia, 08/12/1905).

En estos años no solo se solicitaron patentes de invención de máquinas de fotografía automática, también hubo quien introdujo mejoras en aparatos ya existentes. Es el caso de Marcos Sugrañes a quien se le concedió una patente por "Mejoras en las máquinas destinadas a obtener automáticamente fotografías" el 23 de septiembre de 1892. Ese mismo año un grupo de ingenieros formado por Pedro Cabanach, Francisco Güell, Miguel Petit, Ramón Fábrega, Marcelino Fábrega y Juan Güell Bergés solicitó asimismo una patente por "Perfeccionamientos introducidos en las máquinas fotográficas automáticas". En este caso la patente se puso en práctica el 32 de enero de 1895, caducando el 2 de noviembre de 1898.

En torno a la fotografía automática también se constituyeron empresas dedicadas a la invención y explotación de estos aparatos. En 1893, la primera de estas empresas, la Sociedad Autofotográfica de Barcelona, solicita dos patentes. Una por "Una máquina autofotográfica destinada a la producción automática de fotografías" [Anexo 5.2. Figuras 7 y 8] y otra por "Un procedimiento químico para la obtención de placas fotográficas secas ferro-tipias para la obtención de positivos directos por reflexión". Este hecho queda registrado en la prensa que además añade:

Según sabemos, esta Sociedad se propone explotar en breve dichas máquinas, que resolverán prácticamente el problema tantas veces anunciado y ensayado sin éxito, como el de la fotografía automática. Merece la nueva Sociedad el mayor éxito en su empresa.

Aunque según el registro de la Oficina Española de Patentes y Marcas la patente número 14.776 correspondiente a la máquina autofotográfica se puso en práctica el 4 de noviembre de 1895, no se tiene constancia de la instalación de estos aparatos en Barcelona.

Dos de los aparatos que tuvieron más éxito en Europa, los inventados por Ashton Wolff y por Conrad Bernitt, también llegaron a España. El Bosco, la máquina de fotografía automática diseñada por Bernitt y presentada en la Primera Exposición Internacional de Fotografia Amateur celebrada en la Kunsthalle de Hamburgo en 1893 (Pellicer, 2010: 17), no consta en el registro de patentes de invención de la OEPM pero es conocida su presencia en Madrid gracias a la prensa de la época. En 1897 El Globo, La Iberia, La Correspondencia de España y El Imparcial se hacían eco de la instalación de este "autómata fotográfico" en el pórtico del teatro Apolo, "que en el breve espacio de tres minutos y mecánicamente hace el retrato de una persona" (La Iberia, 28/11/1897). Al igual que en los casos anteriores, el Bosco producía ferrotipos, por lo que carecía de una de las peculiaridades del fotomatón que todos conocemos: la tira de imágenes. Lo 
que se podía obtener en este tipo de máquinas era una imagen única, una versión barata e instantánea del ya antiguo daguerrotipo.

Ya entrado el siglo XX, en concreto en 1909 se le concedió una patente a Henry Ashton Wolff por un "Aparato automático de fotografía sobre papel o tarjeta postal". Diez años después, el 29 de junio de 1919 Juan Cualquiera escribía en la revista Blanco y Negro un reportaje dedicado a este aparato, describiendo pormenorizadamente el proceso por el cual, tras la introducción de una moneda se activa el mecanismo encargado de hacer la fotografía (en este caso solo una), revelarla, fijarla y entregarla al cliente cuatro minutos después. El aparato de Wolff incorporaba mejoras con respecto a otras máquinas. Por ejemplo, incluía un mecanismo por el cual los químicos se renovaban constantemente, consiguiendo con ello que las fotografías resultantes estuviesen siempre bien reveladas y fijadas. Además también se vigilaban mucho los tiempos y que todas las operaciones se realizasen debidamente. Sin embargo seguía utilizando un proceso fotográfico arcaico abocado a desaparecer: la ferrotipia.

De algunas máquinas sólo tenemos conocemos su existencia gracias a la prensa. Es el caso del aparato de fotografía automática inventado por Luther G. Simjian:

En los Estados Unidos es cosa conocida y generalizada los restaurantes sin camareros, las abacerías sin dependientes y otras clases de tiendas o establecimientos en los que el público se sirve a sí mismo. Ahora se ha inaugurado también la fotografía automática. Luther G. Simjian ha inventado una cámara verdaderamente original, que no necesita fotógrafo. El objetivo está oculto tras un espejo, ante el cual se sienta la persona, que toma la actitud y expresión que más le guste y sólo necesita oprimir una perilla para que el pequeño espejo descienda y deje en su lugar la máquina que hace la fotografia. Una combinación de espejos permite a la persona que se retrata adoptar la posición que desee, incluso de perfil, aunque haya observado el inventor-según dicen- que muy pocas mujeres, sobre todo, se deciden a fotografiarse de esta manera. (Ondas, 23/07/1932).

En 1911, otros españoles inventaron un "aparato fotográfico automático" [Anexo 5.2. Figura 9], que en este caso se puso en práctica a partir de 1914, caducando la patente en 1922. La máquina de los catalanes Claudio Baradat Guillé y Francisco Bosch carece de cabina y está coronada por una fuente de iluminación, asemejándose su aspecto al del aparato que aparece en la película Welcome Danger de 1929.

A diferencia de lo que históricamente suele ocurrir, el invento de Josepho llegó a España poco después de haber sido patentado en Estados Unidos. Lo mismo sucedió con otros modelos de fotomatón, como el patentado por la entidad Poso-Graph Corporation Ltd. de Londres y comercializado por la Sociedad Española de Fotografía Automática bajo en nombre comercial de FOTODIN, algo que ya entonces pareció sorprender: "aunque en España estamos acostumbrados a conocer con gran retraso los 
adelantos europeos, ahora no va a ser así: Madrid será una de las primeras capitales que conozcan el FOTODIN, porque se ha constituido una importante empresa que va a propagar por España este invento" (Estampa, 04/06/1929).

La patente de invención del conocido como Photomaton [Anexo 5.2. Figura 10] fue concedida a Josepho en 1925 y tan solo cuatro años más tarde, el 10 de enero de 1929 se cedió a José $\mathrm{M}^{\mathrm{a}}$ Bolibar, en representación de la Sociedad Anónima Española Photomaton "La Fotografía Perfecta" el permiso de explotación del objeto de dicha patente. El aparato de Josepho resolvía, al fin, el problema del procedimiento fotográfico. Desterrando el anticuado ferrotipo, Anatol Josepho no solo inventó una máquina de fotografía automática sino que creó todo un sistema de fotografía sobre papel que no necesitaba negativo de película, sino que era un positivo directo. Por este motivo su aparato fue el que definitivamente se tomó como modelo para el fotomatón químico que se mantuvo en funcionamiento desde entonces hasta los años 90 del siglo pasado.

\subsection{LAS EMPRESAS DE FOTOGRAFÍA AUTOMÁTICA EN ESPAÑA}

Barcelona era una de las ciudades más pujante de la España de finales del XIX y también una de las más industrializadas. Además su proximidad a Francia y por ende a Europa siempre ha jugado a su favor a la hora de incorporar novedades ya sea en el campo de la tecnología, de la ciencia o de las artes. Es este el motivo principal por el que la primera empresa de fotografía automática en España estaba radicada en esta ciudad, y por el que muchos de los inventores españoles de aparatos precedentes del fotomatón fueran catalanes, como es el caso de Juan Cantó. El segundo epicentro de la industria española a finales del siglo XIX y principios del XX, tras la ciudad condal, era Bilbao. Por este motivo no es de extrañar que fuera aquí donde se constituyó, en 1928, la Sociedad Anónima Photomaton "La Fotografía Perfecta", que obtuvo el derecho de explotar industrialmente en España, Portugal y sus Colonias la máquina patentada por Josepho.

\subsubsection{LA SOCIEDAD AUTO-FOTOGRÁFICA DE BARCELONA (1893)}

La primera empresa española dedicada a la construcción, explotación y venta de aparatos de fotografía automática de la que tenemos constancia es la Sociedad Auto-fotográfica de Barcelona. Constituida en 1893 por Pedro Cabanach, Francisco Güell, Miguel Petit, Ramón Fábrega, Juan Güell y Vergés, Marcelino Fábrega, y Rafael Cabret. Todos ellos a excepción de este último, habían solicitado con anterioridad a la creación de la sociedad una patente por "perfeccionamientos introducidos en las máquinas fotográficas automáticas. El capital inicial de la empresa era de quinientas pesetas y fue nombrado gerente de la sociedad Francisco Güell. Los beneficios y pérdidas debían repartirse por igual entre los socios según se establece en el documento de inscripción de la sociedad en el registro mercantil de Barcelona. Esta empresa estuvo activa hasta 1913, momento en el que se disuelve. 


\subsubsection{LA SOCIEDAD ANÓNIMA PHOTOMATON LA FOTOGRAFÍA PERFECTA (1928)}

El primer estudio Photomaton en abrir sus puertas en España fue el de Barcelona, que se inauguró el 17 de febrero de 1929. Estaba situado en la céntrica calle de Pelayo 56, muy cerca de los célebres almacenes El Siglo. La ubicación de estos establecimientos en zonas comerciales y del centro de las ciudades no era casual. Además de en El 30 de marzo de ese mismo año se abrió un estudio Photomaton en Madrid, en un local de la calle Arlabán esquina con Sevilla. En este establecimiento trabajó el "artista fotógrafo" Miguel Andrés, de origen granadino. Aunque se desconoce cuanto tiempo estuvo abierto este negocio, Miguel Andrés solo pudo colaborar realizando "ampliaciones artísticas" un par de años puesto que en 1931 figura activo en San Sebastián (Rodríguez Molina y Sánchez Alfonso, 2013: vol II. 817). En total se llegaron a abrir quince estudios Photomaton en España en los años 30. La tira de seis fotografías costaba una peseta y cincuenta céntimos y el proceso seguido por el cliente, cuya facilidad y sencillez se destacan en todos los medios, era el siguiente:

El que desea retratarse no tiene para ello más trabajo que el que emplearía para pesarse en una báscula automática. Penetra en una especie de cabina; se sienta en un taburete giratorio; coloca una pieza en la ranura de la máquina; permanece diez y seis segundos ante la lente, adoptando las "poses" que estime conveniente, y ocho minutos después, por el dorso de ésta aparece una amplia tira de cartulina con seis fotografias impecables, acabadas, de cuya naturalidad y perfección es el interesado el primero en sorprenderse. (La Vanguardia, 16/02/1929).

Los estudios Photomaton contaban con asistentes encargados de explicar el proceso a un público al que en un primer momento le resultaba difícil comprender cómo una máquina era capaz de hacer por si sola todas las operaciones que implican la toma y el procesado de una serie de fotografías en un espacio de tiempo tan reducido. La cabina estaba equipada con cinco bombillas de 400 vatios, una cámara con un objetivo que ofrecía gran definición de imagen y un taburete. En lugar de película, Josepho ideó un sistema por el cual se generaba un positivo directo sobre la tira de papel. Para revelar las fotografías el papel se pasaba mecánicamente por diferentes compartimentos con revelador, agua y fijador. Después de un lavado final con agua, las tira se secaba y salía por la parte de atrás de la máquina. En ese momento, una luz indicaba al próximo cliente que el aparato ya estaba preparado para la siguiente toma. Para las ampliaciones se hacían copias por contacto de las fotografías en papel sobre un negativo. (Goranin, 2009: 26-27). 


\subsubsection{LA SOCIEDAD ESPAÑOLA DE FOTOGRAFÍA AUTOMÁTICA (1929)}

La otra empresa que tenía por misión la explotación, venta y alquiler de aparatos automáticos de fotografía era la Sociedad Española de Fotografía Automática. Constituida en Madrid el 3 de junio de 1929, tenía un capital inicial de 1.500 .000 pesetas. El modelo utilizado por esta compañía era el patentado por la empresa inglesa Poso Graph Parent Corporation. La principal diferencia de este aparato con respecto al de Josepho es que en este caso el procedimiento incluía el paso de un negativo de película a un positivo en papel. La Sociedad Española de Fotografía Automática tenía su sede en la Avenida Pi y Margall (Gran Vía), 9. Los primeros dispositivos se colocaron, con motivo de la XXI Fiesta del Sainete, en el Teatro Apolo, donde décadas antes se había instalado el Bosco Automat de Conrad Bernitt. Además como parte de su campaña promocional, la empresa hacía obsequiaba a todas las espectadoras interesadas con ocho fotografías hechas en Fotodin:

\section{(...) En el vestíbulo de butacas, en el de palcos y en el de anfiteatros} habrá sendos aparatos de la Sociedad Española de Fotografia Automática Fotodin, y todas las señoras que quieran podrán retratarse completamente gratis, recibiendo ocho fotografias en postura diferente. ¡Vaya bellezas que van a desfilar ante los objetivos! (ABC, 08/06/1929).

El precio por una tira de ocho retratos más una ampliación en blanco y negro era de dos pesetas; en sepia de dos pesetas y media; y de tres pesetas si se querían la fotografía coloreada a mano (La Libertad, 30/07/1929). El tamaño del aparato era de 1,65 por 0,60 metros y las ampliaciones iban desde el 6 por 7 al 60 por 90 . Según los anuncios publicitarios de la prensa escrita, los negativos eran conservados por la empresa indefinidamente, con lo que los clientes podían encargar a posteriori ampliaciones de sus retratos "en cualquier tamaño o postura". También se indica en la publicidad la próxima instalación de dispositivos preparados para retratar de cuerpo entero y para fotografías de grupos (Heraldo de Madrid, 07/04/1929).

El éxito comercial de Fotodin llevo a la Sociedad Española de Fotografía Automática a "anticipar la instalación de algunos de sus locales propios, entre ellos el de Peligros 9; Glorieta de Cuatro Caminos y Puente de Vallecas, que, unidos al de Madrid-París, ya instalado, podrán por el momento atender el servicio" (ABC, 21/06/1929) Sin embargo, con posterioridad al año de 1929 se pierde la pista de esta empresa, lo que hace suponer que su notoriedad fue efímera. 


\section{CONCLUSIONES}

En este trabajo se aporta una definición de fotomatón y nuevos datos para la historia de la industria fotográfica en España. Se dan a conocer los nombres de inventores y empresarios y su aportación en esta materia, una información inédita y que se presenta por vez primera en esta investigación.

La industria de la fotografía automática no parece haber tenido en España la relevancia que adquirió en Estados Unidos o Francia, lo cual no resulta sorprendente pues la propia fotografía goza de mayor prestigio e importancia en estos países, ambos cultural e industrialmente más avanzados que España.

No obstante, también a nivel nacional se hicieron esfuerzos por conseguir un aparato que pudiese entregar al cliente una fotografía de manera automática y autónoma desde una fecha muy temprana. Entre 1888 y 1929 se concedieron en España 23 patentes de invención y 2 patentes de introducción de aparatos de fotografía automática, de las cuales tan solo 7 se pusieron en práctica. Algunos inventores españoles realizaron importantes aportaciones al mundo de la fotografía automática, como es el caso de Antonio Durán y Fornel con su "fotógrafo autómata". Sin embargo, ni este ni ningún otro aparato de fotografía automática inventado por un español ha traspasado las fronteras de este país, a diferencia de lo sucedido con los inventos de Conrad Bernitt o de Ashton Wolff, extendidos por todo el territorio europeo.

Dentro del territorio español, el fotomatón ha tenido mayor presencia y relevancia en Barcelona que en el resto de la Península en relación con la importante actividad industrial de la ciudad a finales del siglo XIX y principios del XX y con la receptividad del público barcelonés "amante como ningún otro de todo cuanto significa progreso" (La Vanguardia, 16/02/1929). Es allí donde se instalan los primeros aparatos de fotografía automática (hay constancia a través de la prensa de que los aparatos patentados por Antonio Durán y Fornel se instalan en la ciudad condal). También los primeros inventores (Juan Cantó, Federico Martí, Marcos Sugrañes) y la primera empresa (Sociedad Autofotográfica) son catalanes.

El fotomatón cumplía, en sus orígenes, una doble función. Por un lado formaba parte del conjunto de máquinas de recreo que, colocadas en ferias o centros comerciales, tenían como finalidad divertir a los usuarios y por otro facilitaba retratos a aptos para todo tipo de carnets y kilométricos a un precio asequible. Esto hizo que los fotógrafos profesionales se sintieran amenazados y presionaran a las autoridades para que no admitieran en documentos oficiales las fotografías hechas en este tipo de dispositivos. No obstante, el Estado acabó aceptando como válidas este tipo de imágenes. Pese al recelo que los profesionales del sector tenían fotomatón, no se dispone de información que permita afirmar que el fotomatón haya perjudicado en gran medida este tipo de negocios, puesto que los productos que ambos servicios ofrecen responden a diferentes demandas por parte de los clientes.

Aunque en la prensa se indica que los estudios Photomaton y los aparatos Fotodin tuvieron gran éxito comercial, parece que éste no fue duradero, y una vez 
pasado el furor inicial asociado a toda novedad, ambos negocios empezaron una fase de declive que culminó en su cierre y en la desaparición de ambas empresas. Esto se deduce de su escasa presencia mediática con posterioridad a 1930 y de la falta de documentos que indiquen lo contrario. Dentro de las posibles causas del fracaso de los primeros establecimientos y de los primeros aparatos de fotomatón en España es posible señala, por una parte el estallido de la Guerra Civil en 1936 y, por otra, la tardía implantación de la fotografía en el carnet de identidad, que se hizo efectiva en 1946.

A pesar de que muchos de los interrogantes que se planteaban al inicio del trabajo se han esclarecido tras la labor de investigación otros han quedado sin resolver. ¿Cuántos estudios Photomaton llegó a haber en España y en que año se cerraron? ¿Cuánto tiempo estuvieron instalados los aparatos Fotodin? ¿Qué volumen de fotografías se produjeron en estas máquinas y que ha sido de estas imágenes? ¿Qué supuso verdaderamente el fotomatón para la industria fotográfica en nuestro país? Estas cuestiones quedan pendientes a la espera de que aparezcan nuevas fuentes que puedan aportar información al respecto en futuras investigaciones.

\section{REFERENCIAS BIBLIOGRÁFICAS}

ABOUT, Ilsen (2012). "Identités automatiques: Le Photomaton et l'encartement des individus" en CHÉROUX, Clément; STOURDZÉ, Sam (dir.). Derrière le rideau. L'esthétique Photomaton. Arles: Éditions Photosynthèses, pp. 263-271.

CARRERO DE DIOS, Manuel (2001). Historia de la industria fotográfica española. Girona: Curbet Comunicació Gràfica.

CHÉROUX, Clement (2012). "Le degré zero du portrait. Pourquoi le Photomaton fascine" en CHÉROUX, Clément y STOURDZÉ, Sam (dir.) (2012). Derrière le rideau. L'esthétique Photomaton. Arles: Éditions Photosynthèses, pp. 27-37.

FRIZOT, Michel (2001). Nouvelle histoire de la photographie. París: Larousse. FONTCUBERTA, Joan (2012). La cámara de Pandora. Barcelona: Gustavo Gili. GORANIN, Näkki (2008). American photobooth. New York: W. W. Norton Co.

GOSIO, Paolo y CHIESA, Gabriele (2013). Dagherrotipia, ambrotipia, ferrotipia. Youcanprint.

HINES, Babbette (2002). Photobooth. New York: Princeton Architectural Press.

LÓPEZ MONDEJAR, Publio (2005). Historia de la fotografia en España: fotografia y sociedad desde sus origenes hasta el siglo XXI. Barcelona: Lunwerg.

MATHYS, Nora; TIMBY, Kim (2012). "Photographies d'amitié: De l'usage collectif du Photomaton" en CHÉROUX, Clément y STOURDZÉ, Sam (dir.). Derrière le rideau. L'esthétique Photomaton. Arles: Éditions Photosynthèses, pp. 273-281.

PELLICER, Raynal (2010). Photobooth: the art of the automatic portrait. New York: Abrams.

RODRÍGUEZ MOLINA, Ma José; SÁNCHEZ ALFONSO, José Ramón (2013). Directorio de Fotógrafos en España (1851-1936). 2 vol. Valencia: Diputació de Valencia Arxiu General i Fotografic. 
SÁNCHEZ VIGIL, Juan Miguel (2006). El documento fotográfico: Historia, usos, aplicaciones. Gijón: Ediciones Trea.

SÁNCHEZ VIGIL, Juan Miguel; FERNÁNDEZ FUENTES, Belén (2005). "La fotografía como documento de identidad" en Documentación de las Ciencias de la Información, vol. 28, pp. 189-195.

SÁNCHEZ VIGIL, Juan Miguel; SALVADOR BENÍTEZ, Antonia (2014). Documentación fotográfica. Barcelona: UOC-EPI.

SOUGEZ, Marie Loup (2009). Historia de la fotografia. Madrid: Cátedra. 


\section{ANEXOS}

\subsection{RETRATOS}

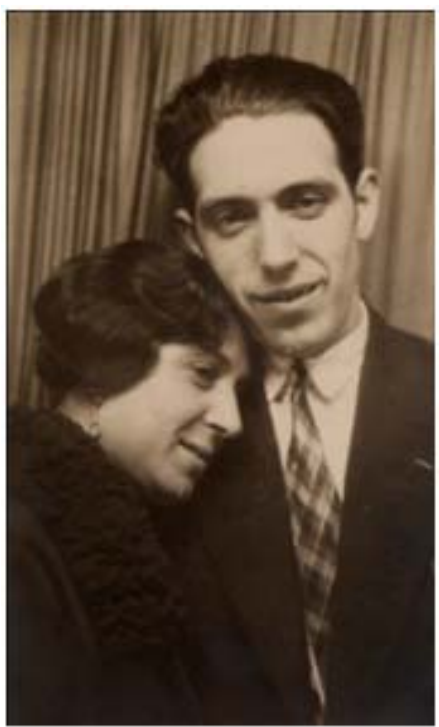

Figura. 1. Retrato de pareja desconocida. Fotodin. Años 30. Colección Celia Vega.

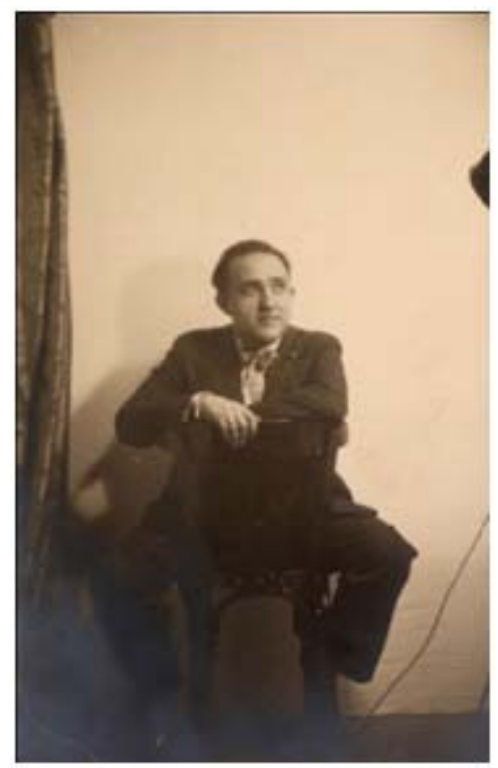

Figura. 3. Retrato de actor de teatro de cuerpo entero. Fotodin. Años 30. Colección Celia Vega.

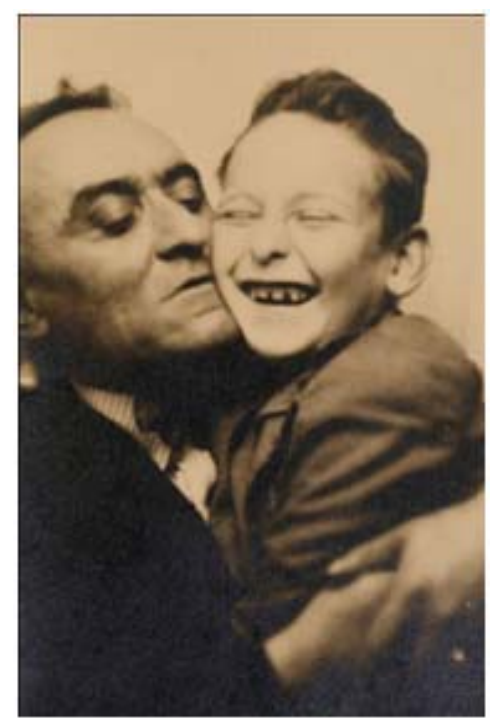

Figura. 2. Retrato de padre e hijo.

Fotodin. Años 30. Colección Celia Vega.

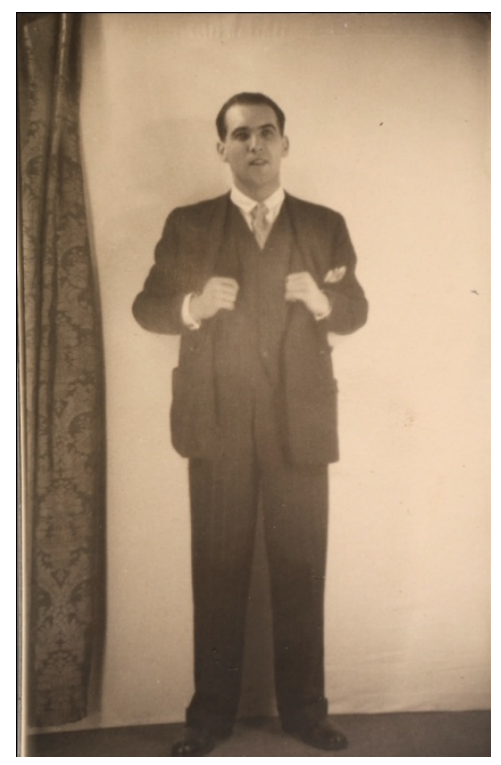

Figura. 4. Retrato de actor de teatro de cuerpo entero. Fotodin. Años 30.

Colección Celia Vega.

Revista General de Información y Documentación Vol. 24-2 (2014) 305-341 
Celia Vega Pérez

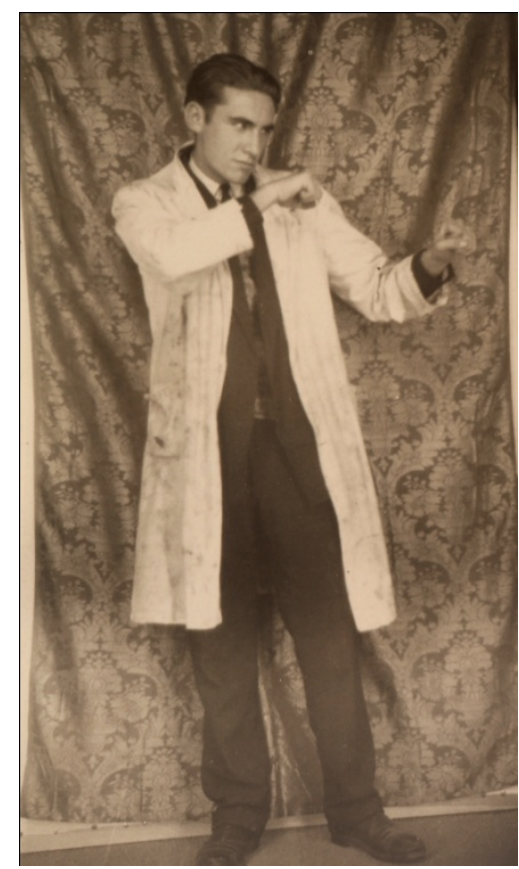

Figura. 5. Retrato de actor de teatro. Fotodin. Años 30. Colección Celia Vega
Orígenes del fotomatón en España (1888-1929)

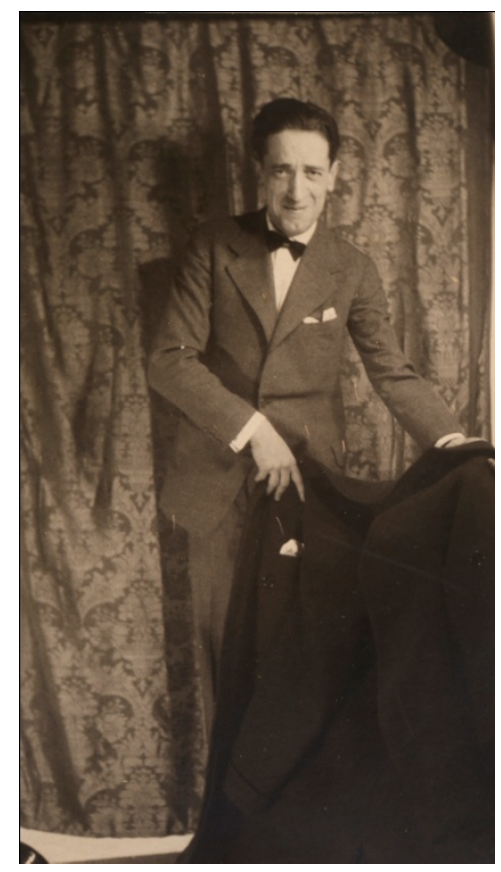

Figura. 6. Retrato de actor de teatro. Fotodin. Años 30. Colección Celia Vega 


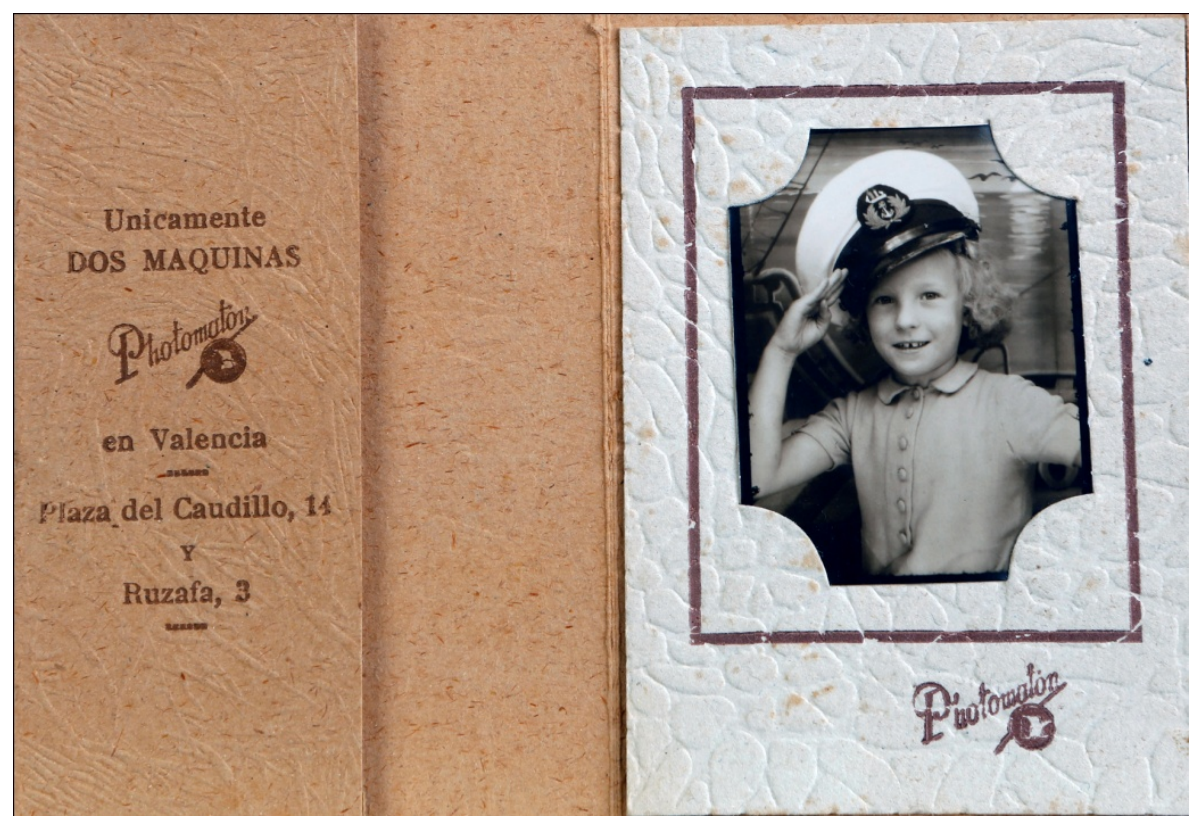

Figura. 7. Retrato de niño con gorro marinero. Estudio Photomaton Valencia. Colección Celia Vega 

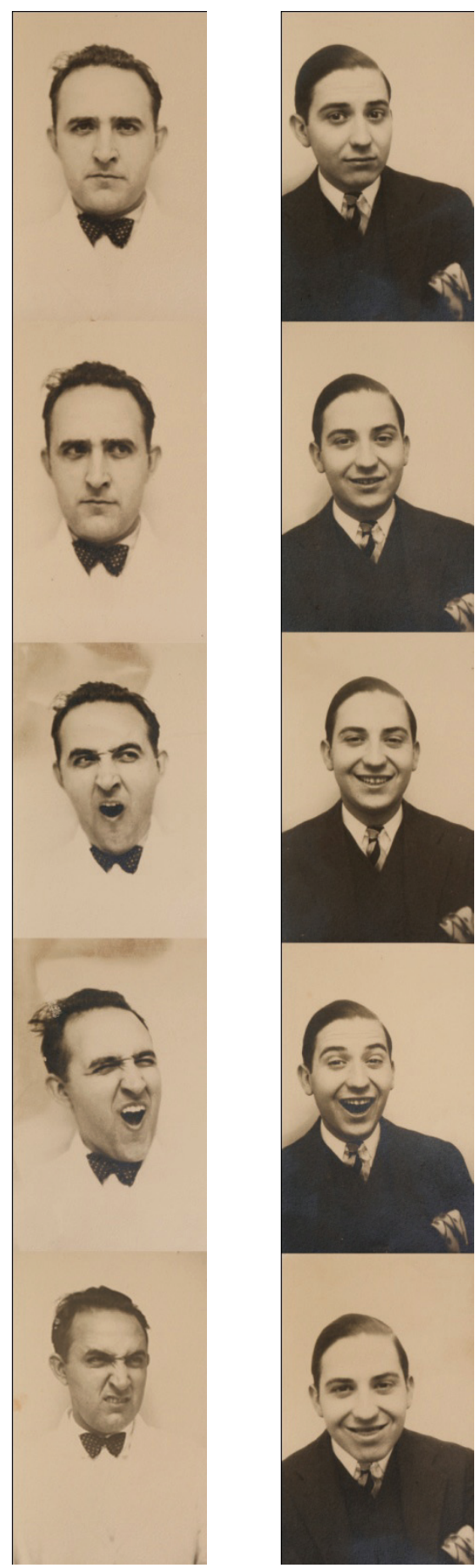

Figuras 8 y 9. Posible ordenación de fotografías de fotomatón en tiras. Fotodin. Retratos de actores de teatro desconocidos. Años 30. Colección Celia Vega 


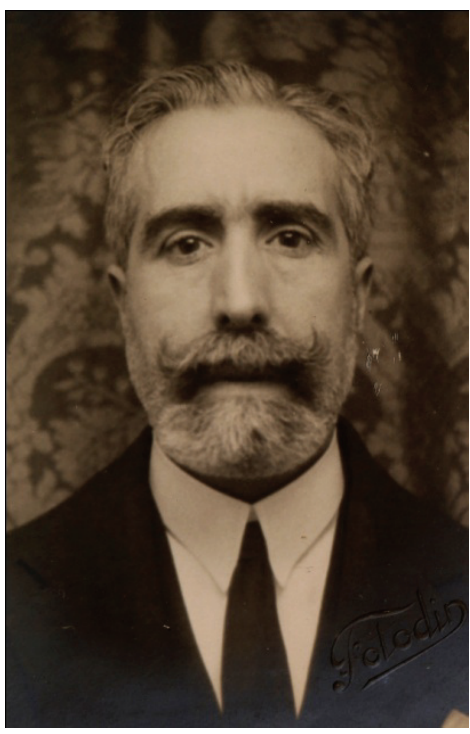

Figura 10. Retrato de actor desconocido. Fotodin. Años 30. Colección Celia Vega

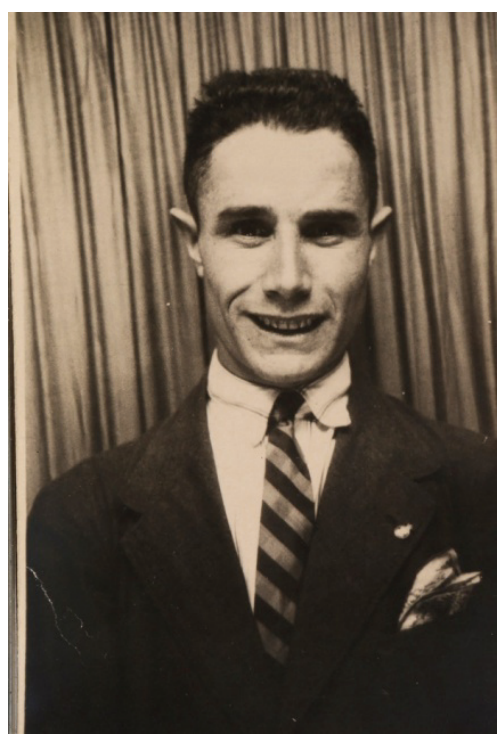

Figura 12. Retrato de actor desconocido. Fotodin. Años 30. Col. Celia Vega

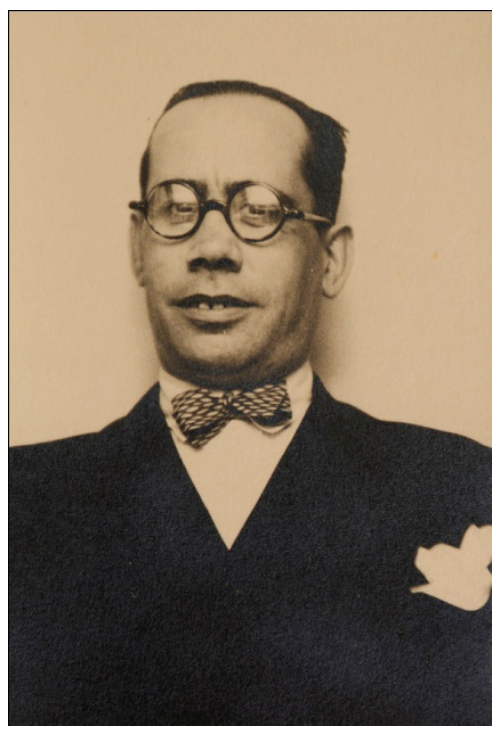

Figura 11. Retrato de actor desconocido. Fotodin. Años 30. Colección Celia Vega

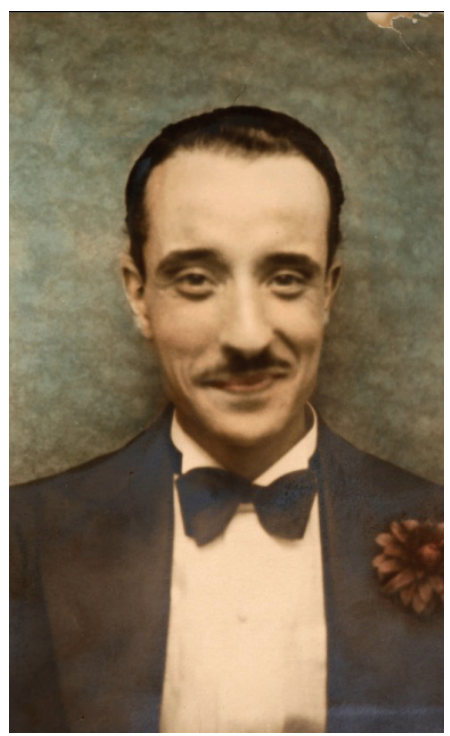

Figura 13. Retrato de actor desconocido coloreado a mano. Fotodin. Años 30. Colección Celia Vega 


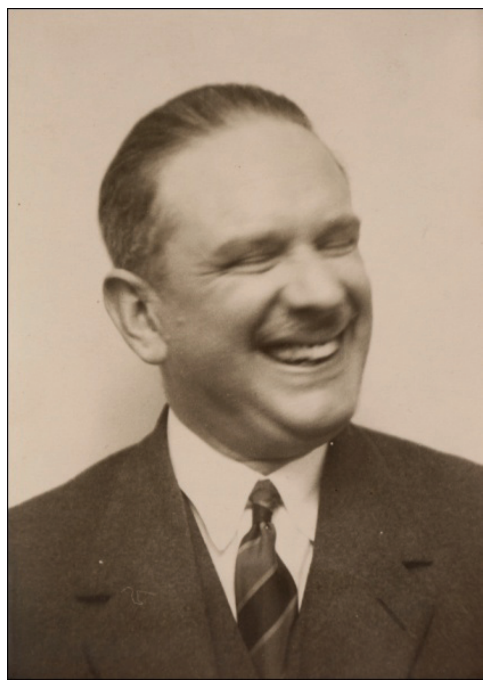

Figura 14. Retrato de actor de teatro. Fotodin. teatro. Años 30. Colección Celia Vega

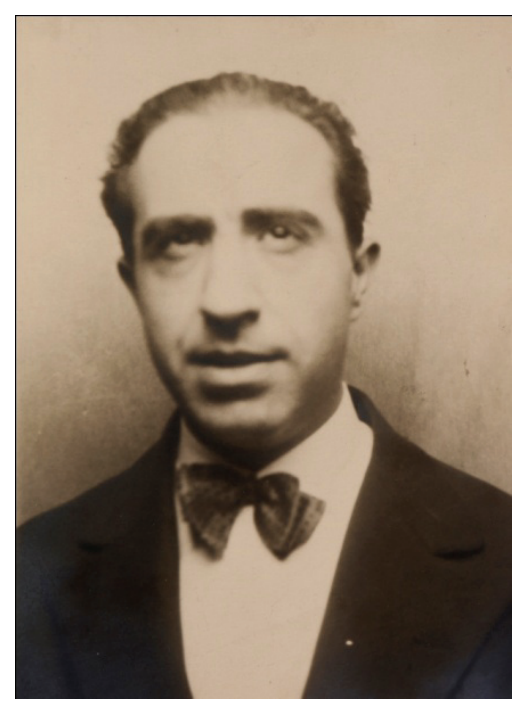

Figura 16. Retrato de actor de teatro. Fotodin. Años 30. Colección Celia Vega

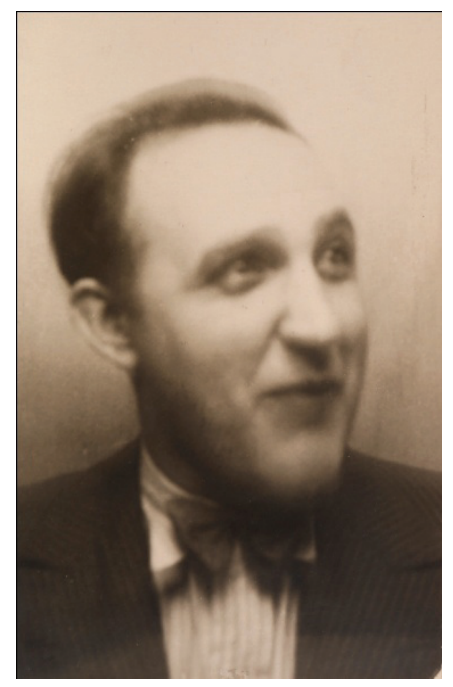

Figura 15. Retrato de actor de Fotodin. Años 30. Col. Celia Vega

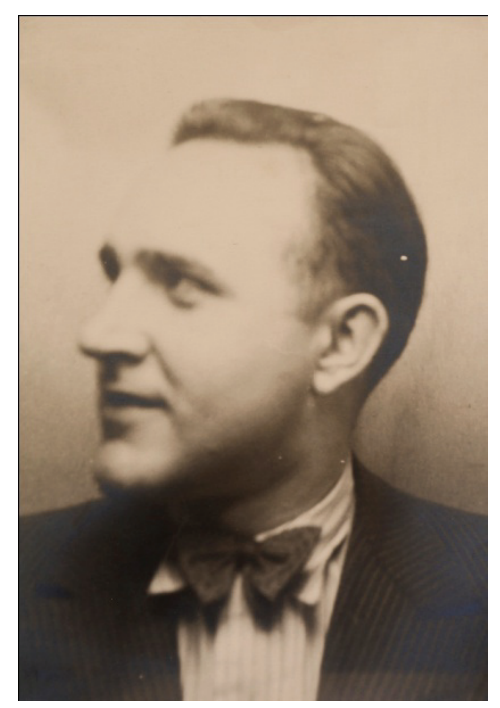

Figura 17. Retrato de actor de teatro. Fotodin. Años 30. Col.Celia Vega 


\subsection{EXPEDIENTES DE PATENTES}

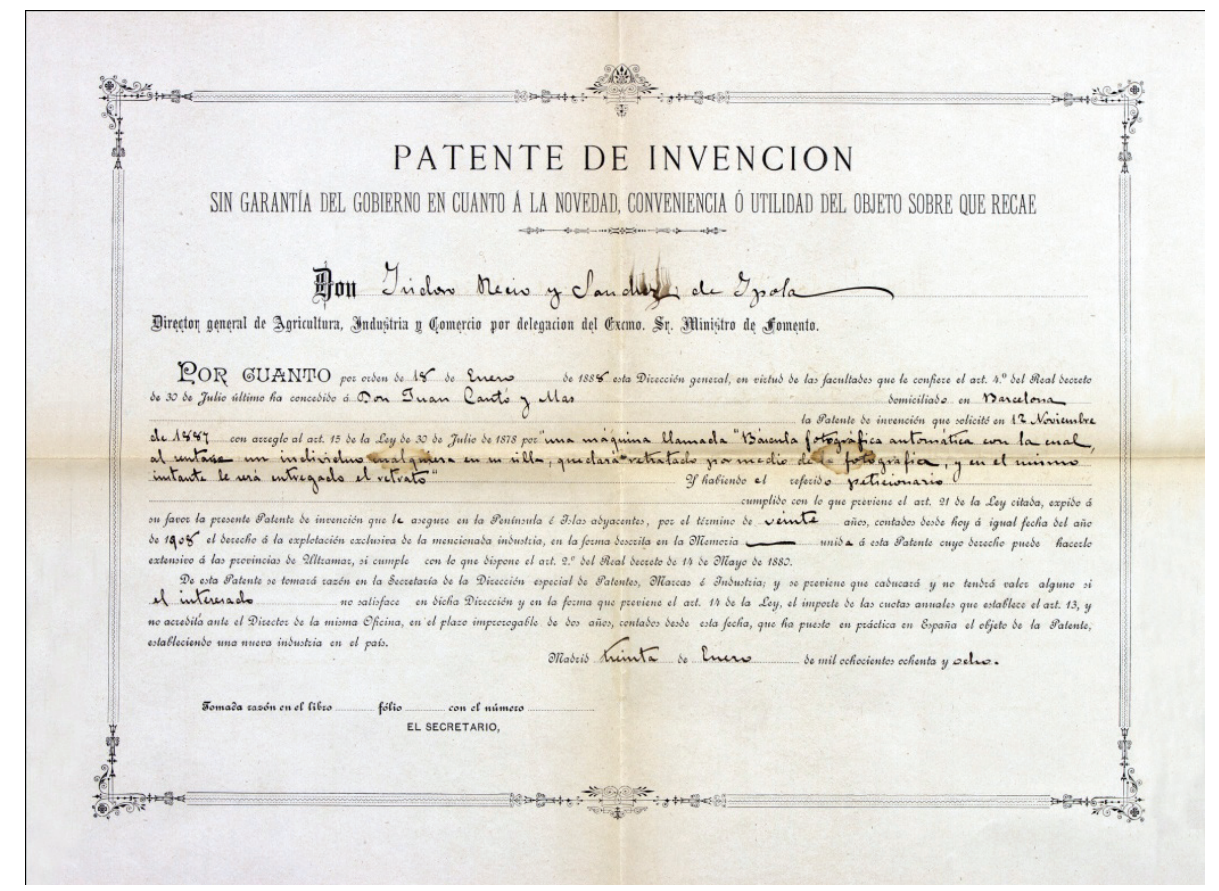

Figura 1. Patente de invención. Don Juan Cantó y Mas, 1888
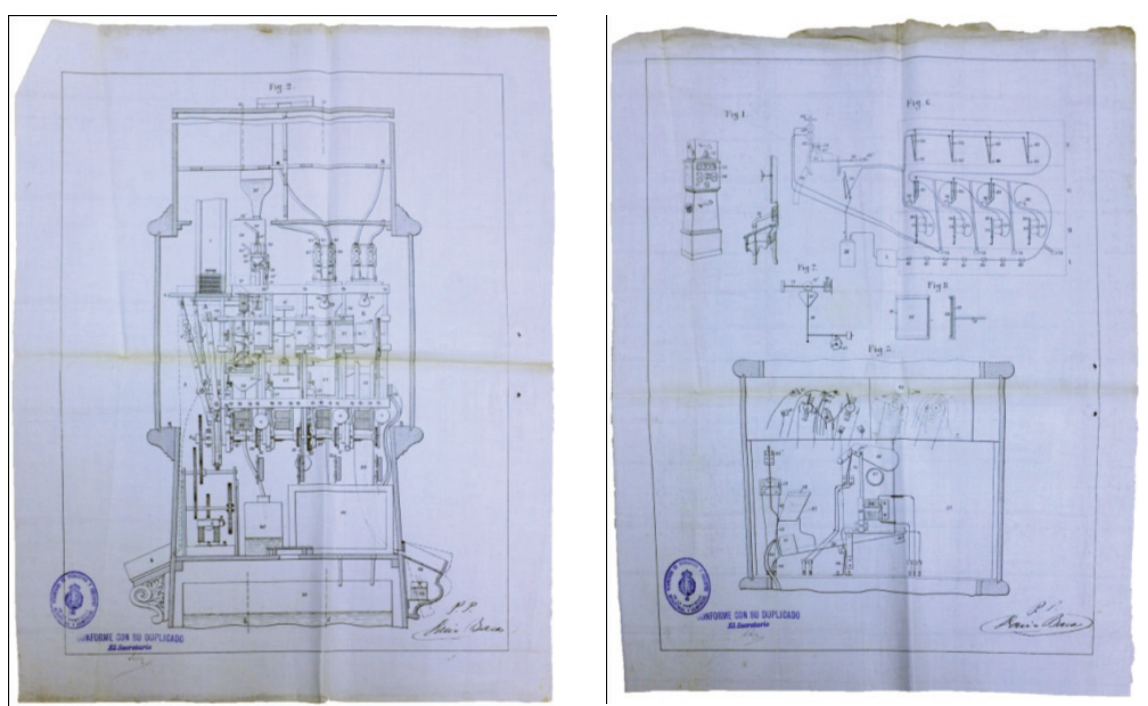

Figuras 2 y 3. Planos del aparato fotográfico automático de Ernest Théophile Enjalbert, 1889 


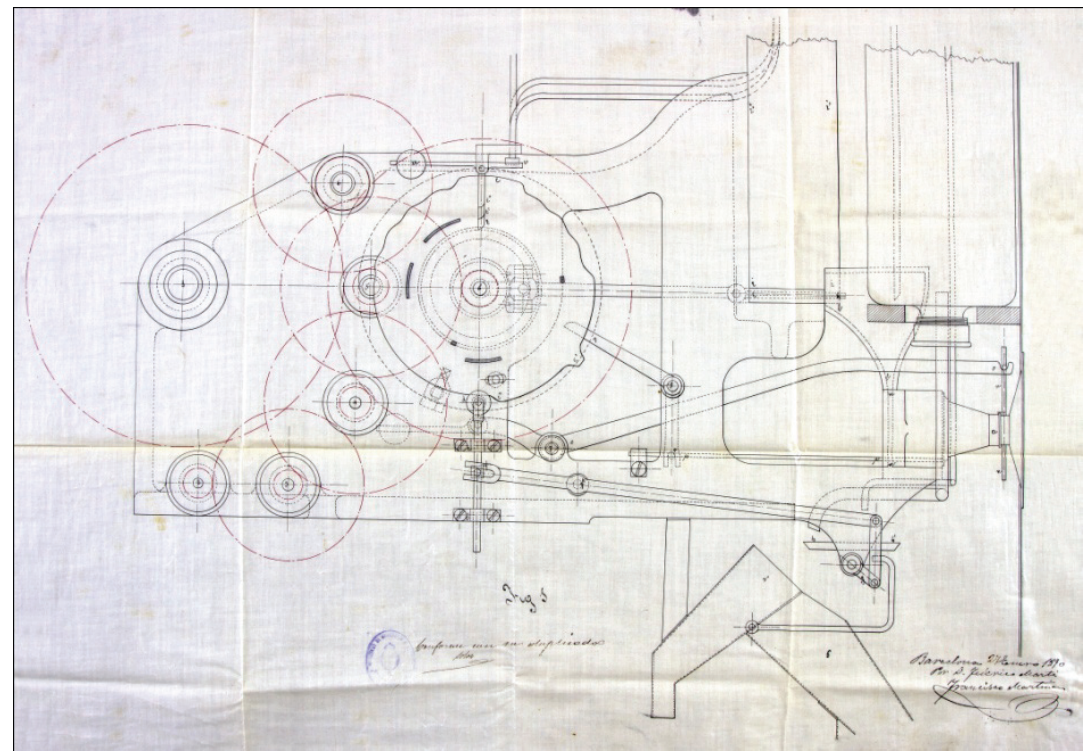

Figura 4. Dibujo de la máquina automática para la obtención de fotografías patentada por Federico Martí Biosca, 1890

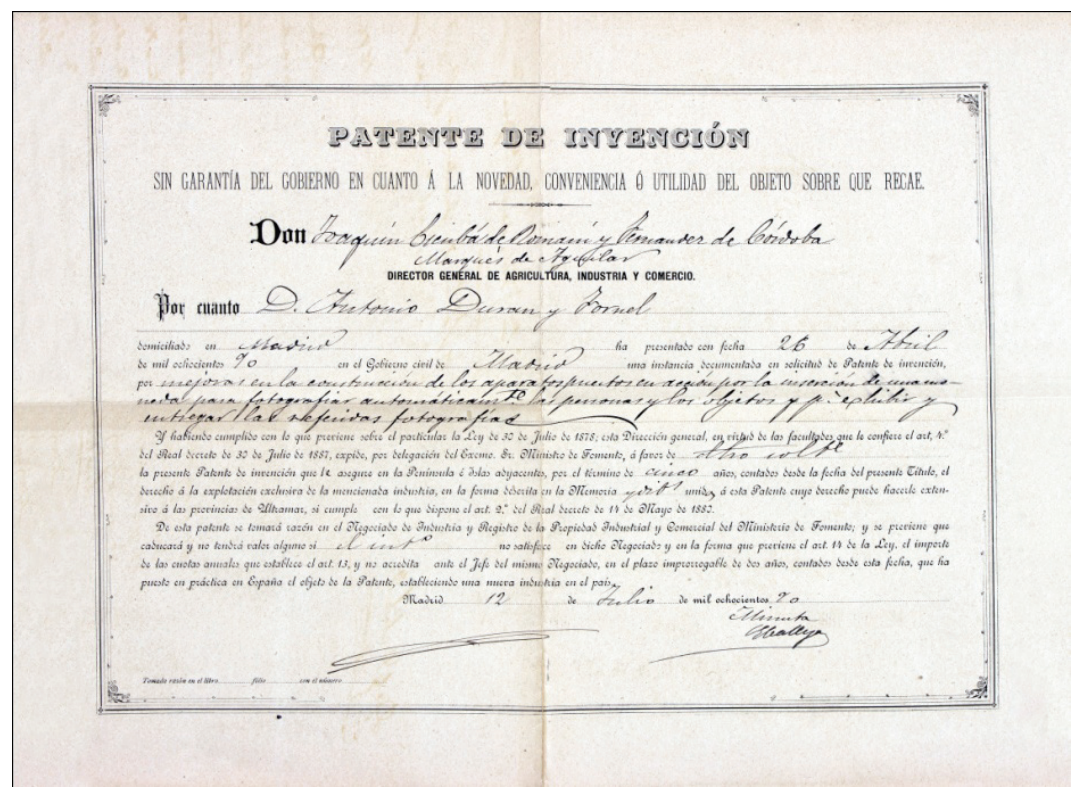

Figura 5. Patente de invención. Antonio Durán y Fornel, 1890 


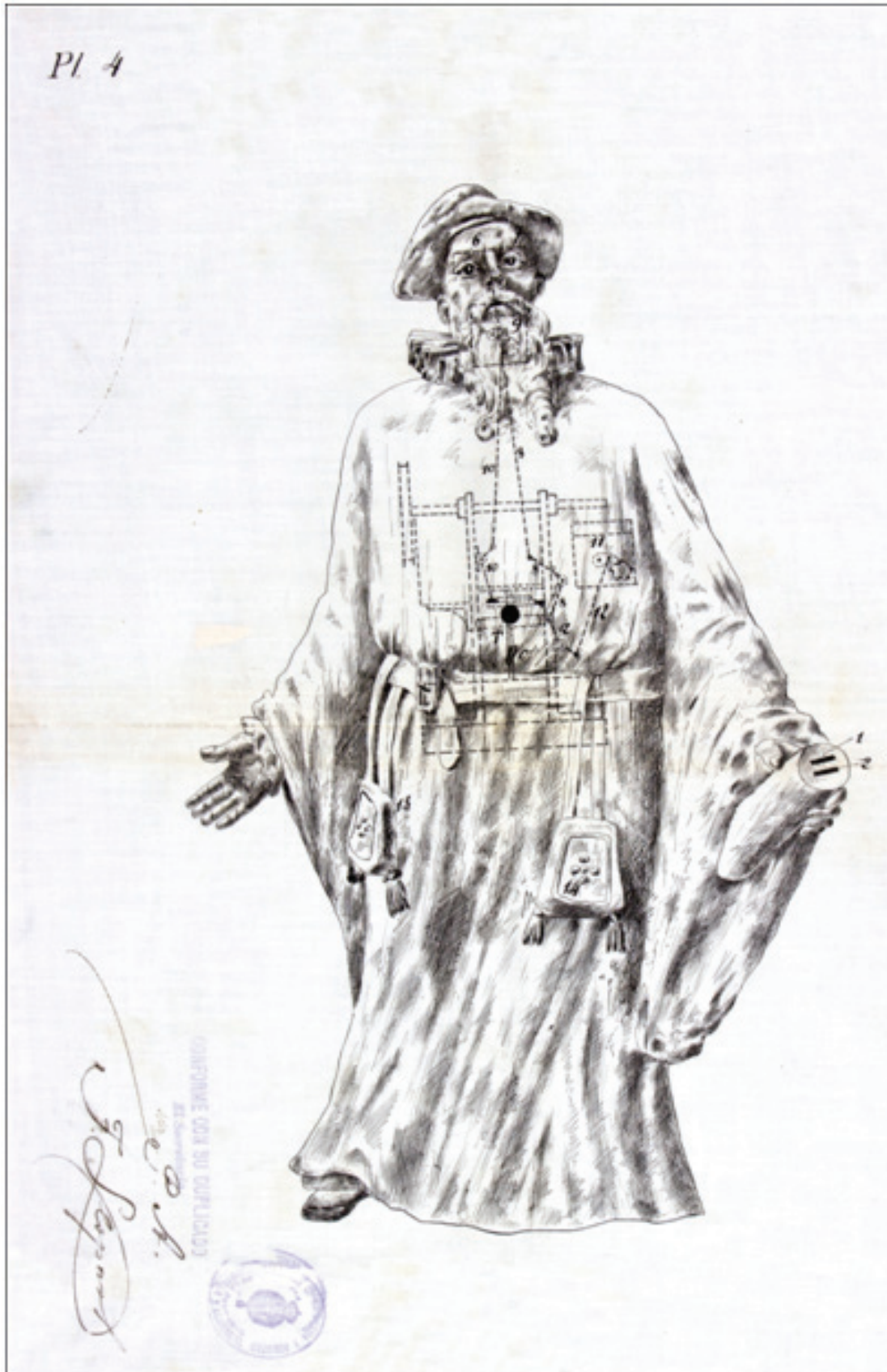

Figura 6. Plano del fotógrafo autómata de Antonio Durán y Fornel, 1891 

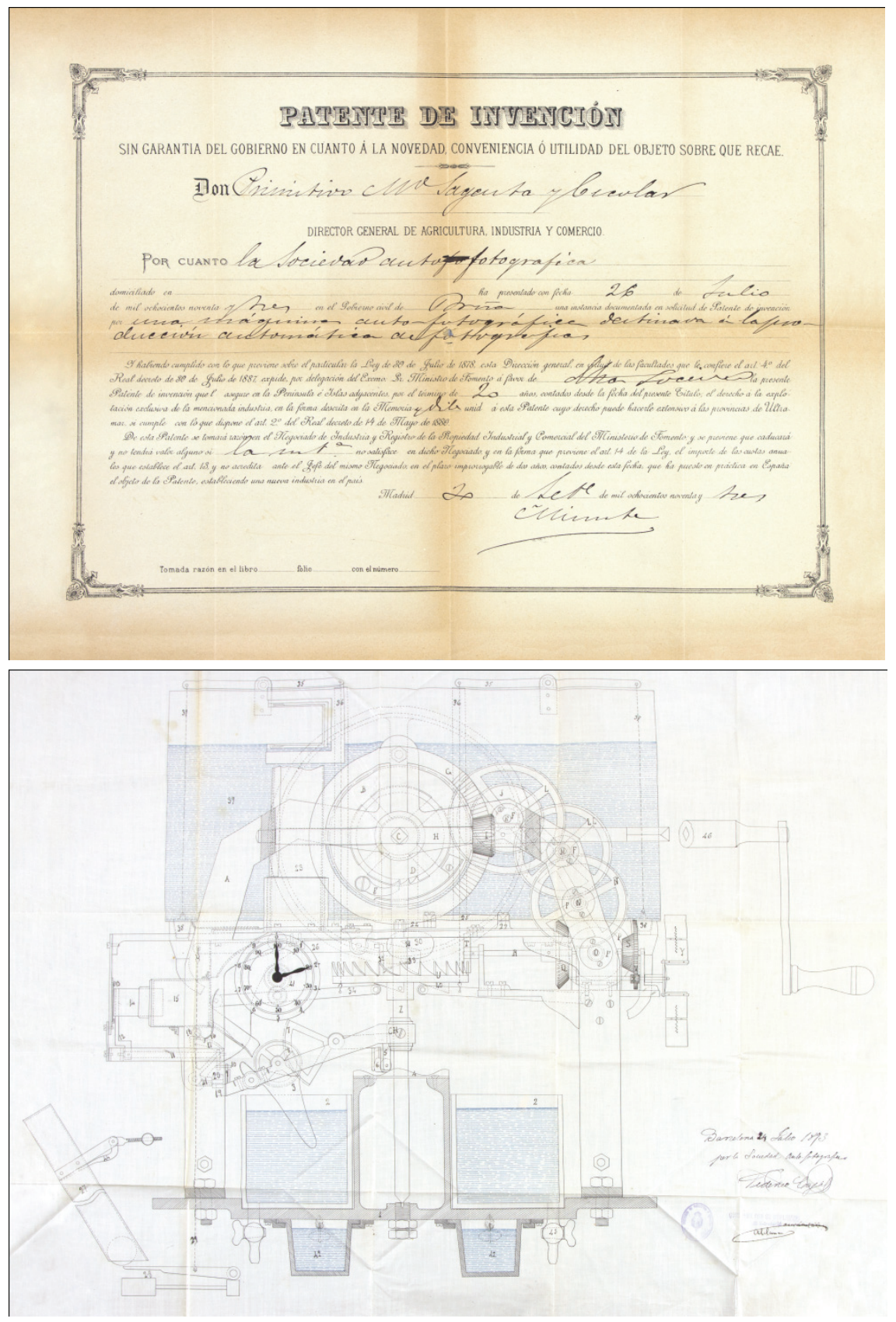

Figuras 7 y 8. Patente de invención. Sociedad Auto-fotográfica, 1893 


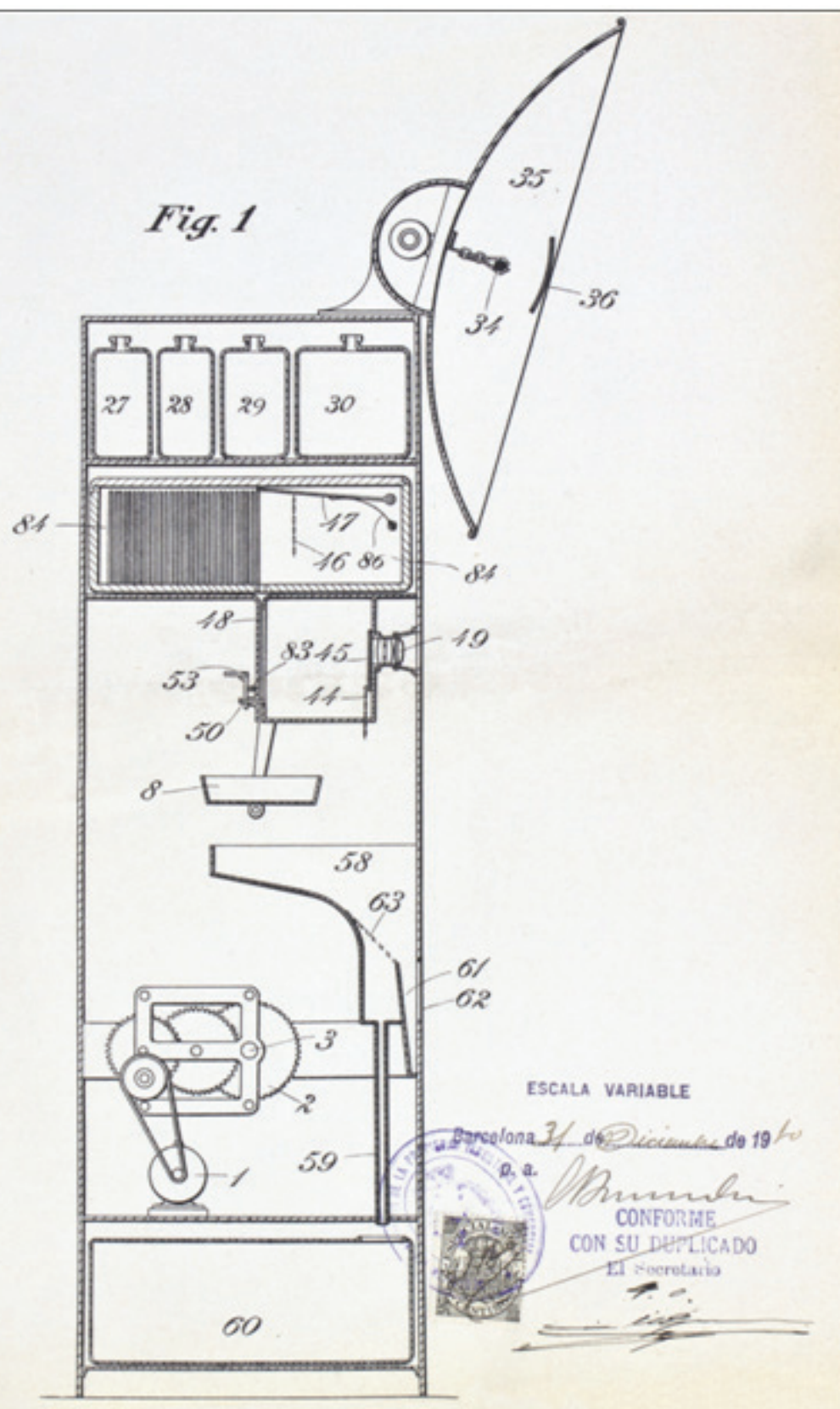

Figura 9. Dibujo del aparato fotográfico automático patentado por Claudio Baradat Guillé y Francisco Bosch, 1911 


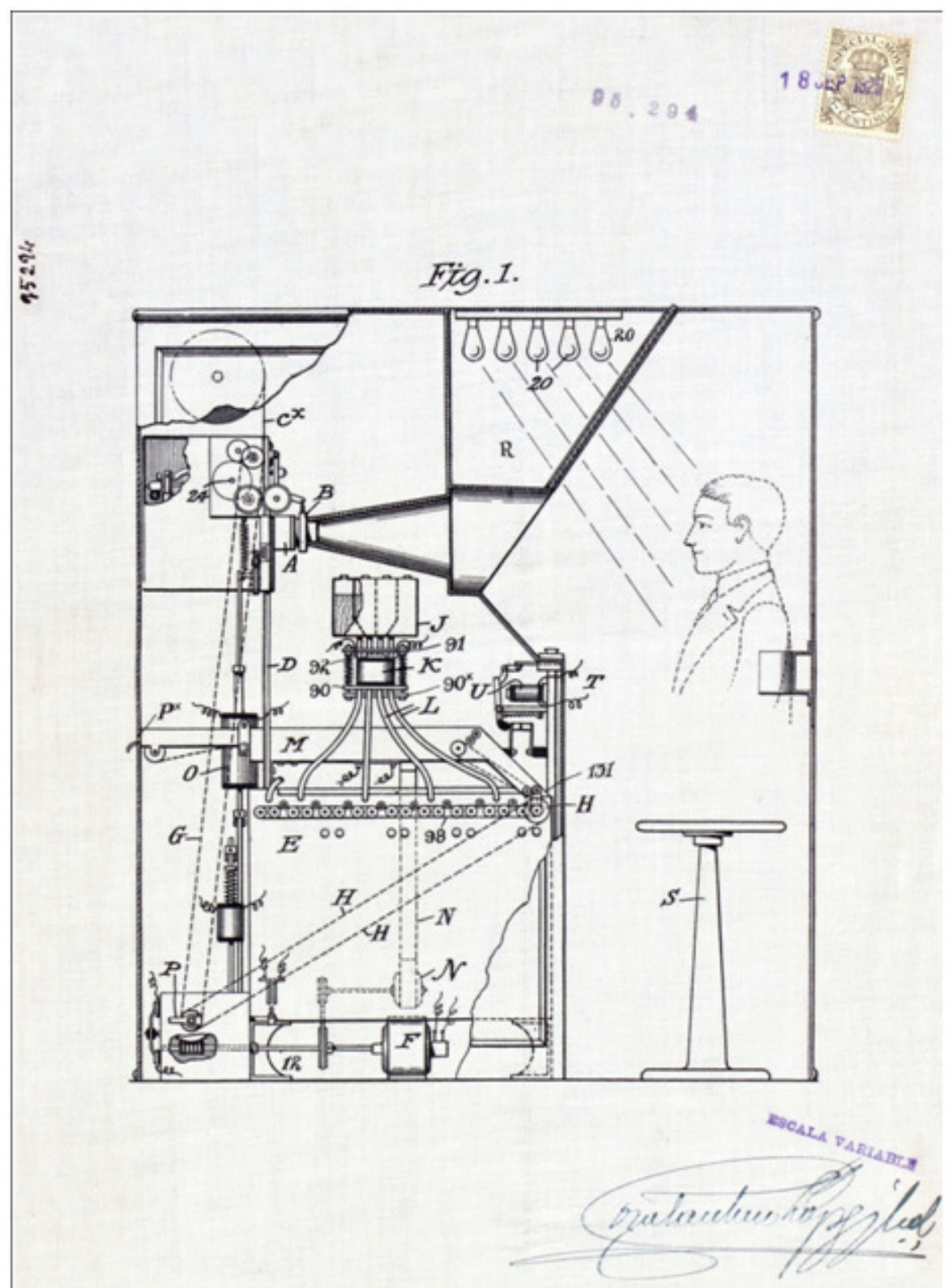

Figura 10. Plano del aparato de fotografía automática patentado por Anatol Josepho en 1925 